\title{
Catalytic Enantioselective Conjugate Reduction of Lactones and \\ Lactams.
}

\author{
Gregory Hughes, Masanari Kimura, and Stephen L. Buchwald.* \\ Department of Chemistry, Massachusetts Institute of Technology \\ Cambridge, Massachusetts, 02139.

\section{Supporting Information}

\section{General Considerations.}

Unless otherwise noted, THF, $\mathrm{Et}_{2} \mathrm{O}, \mathrm{CH}_{2} \mathrm{Cl}_{2}$ and toluene were purchased from J.T. Baker in CYCLE-TAINER ${ }^{\circledR}$ solvent-delivery kegs and vigorously purged with argon for $2 \mathrm{~h}$. The solvents were further purified by passing them under argon pressure through two packed columns of neutral alumina (for $\mathrm{THF}$ and $\mathrm{Et}_{2} \mathrm{O}$ ) or through neutral alumina and copper (II) oxide (for toluene and $\mathrm{CH}_{2} \mathrm{Cl}_{2}$ ). ${ }^{1}$ Dichloroethane and cyclohexane were purchased from EM Science in Drisolv ${ }^{\circledR}$ bottles and were used without further treatment. Fluorobenzene was purchased from Avacado and used as is. Starting materials for substrate synthesis were purchased from commercial sources and used as is. $\mathrm{CuCl}_{\mathrm{CuCl}}$, $\mathrm{CuCl}_{2} \cdot \mathrm{H}_{2} \mathrm{O}$ and $t$-BuONa were purchased from Strem and used as is. PMHS (polymethylhydrosiloxane), ethyl alcohol, 2-propanol and $s$ - $\mathrm{BuOH}$ were purchased from Aldrich and used as is. $t$-AmOH was purchased from Alfa Aesar and used as is. For rate studies, EtOH, $i-\mathrm{PrOH}$, and $s-\mathrm{BuOH}$ from Aldrich Sure/Seal ${ }^{\mathrm{TM}}$ bottles were used, and $t-\mathrm{AmOH}$ was distilled from $\mathrm{CaH}_{2}$ under argon, and then degassed by three freeze/ pump/ thaw cycles. $t$-AmOD (degassed by three freeze/ pump/ thaw cycles) was prepared by quenching a pentane suspension of $t$-AmONa (purchased from Aldrich) with $\mathrm{D}_{2} \mathrm{O}$.

Unless otherwise noted, reactions for the preparation of starting materials were carried out in round bottom flasks under a positive pressure of nitrogen or argon. Unless otherwise noted, conjugate reductions were carried out under nitrogen or argon in Schlenk tubes sealed with Teflon screw caps. Yields refer to isolated yields of compounds of greater than 95\% purity as estimated by capillary GC and ${ }^{1} \mathrm{H}$ NMR. Yields reported in this section refer to a single experiment, while those reported in the tables are the average of two or more runs. 
All new compounds were characterized by ${ }^{1} \mathrm{H}$ NMR, ${ }^{13} \mathrm{C}$ NMR, and IR spectroscopy, in addition to elemental analysis (Atlantic Microlabs, Inc). Nuclear Magnetic Resonance spectra were recorded on a Varian Mercury 300 or a Varian Unity 300 instrument. Infra Red spectra were recorded on an ASI Applied Systems ReactIR 1000 (liquids and solids were measured neat on a DiComp probe). All ${ }^{1} \mathrm{H}$ NMR experiments are reported in $\delta$ units, parts per million (ppm) downfield from tetramethylsilane. All ${ }^{13} \mathrm{C}$ NMR spectra are reported in ppm relative to deuterochloroform (77.23 ppm), and all were obtained with ${ }^{1} \mathrm{H}$ decouling. Melting points (uncorrected) were obtained on a Mel-Temp capillary melting point apparatus. Optical rotations were taken on a Perkin-Elmer 241 Polarimeter. Gas Chromatographic analyses were performed on a Hewlett-Packard 6890 gas chromatography instrument with an FID detector using $25 \mathrm{~m} x$ $0.20 \mathrm{~mm}$ capillary column with cross-linked methyl siloxane as a stationary phase. Chiral High Pressure Liquid Chromatography analyses were performed on a Hewlett-Packard 1100 system with an HP 1100 Diode Array Detector, using the columns and wavelengths mentioned in section III.

\section{Preparation of Substrates}

General procedure for the esterification of alcohols with acryloyl chloride:

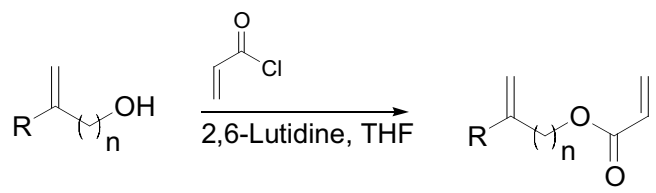

Acryloyl chloride (2 equiv) was added to a $0{ }^{\circ} \mathrm{C}$ solution of alcohol (1 equiv) and 2,6-Lutidine (2 equiv) in tetrahydrofuran (THF) $(0.5 \mathrm{M}$ in alcohol). The mixture was then allowed to warm to ambient temperature and stirred until TLC analysis showed complete consumption of the alcohol. The reaction mixture was partitioned between diethyl ether and $10 \% \mathrm{HCl}$. The aqueous layer was separated and extracted two times with diethyl ether. The organic layers were combined, washed with brine, dried over $\mathrm{MgSO}_{4}$, filtered and concentrated to dryness. The residue was purified by flash chromatography on silica gel.

General procedure for RCM of allylic and homoallylic acrylates:

${ }^{1}$ (a) Pangborn, A.B.; Giardello, M.A.; Grubbs, R.H.; Rosen, R.K.; Timmers, F.J. Organometallics 1996, 15, 1518. (b) Alaimo, P.J.; Peters, D.W.; Arnold, J.; Bergman, R.G. J. Chem. Ed. 2001, 78, 64. 

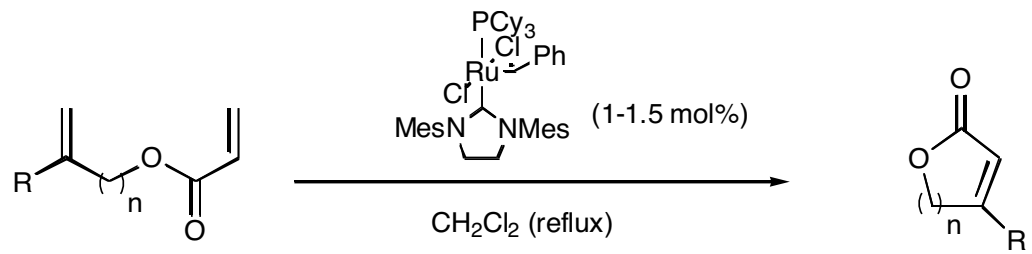

A solution of the carbene complex $(1 \mathrm{~mol} \%)$ in dichloromethane $(1 \mathrm{~mL} / 100 \mu \mathrm{mol} \mathrm{Ru})$ was added via syringe pump to a refluxing solution of diene (1 equiv) in $\mathrm{CH}_{2} \mathrm{Cl}_{2}(4 \mathrm{~mL} / \mathrm{mmol}$ acrylate) over $10 \mathrm{~h}$. The mixture was cooled to room temperature, concentrated to dryness, and the residue was purified by flash chromatography. Kugelrohr distillation was then performed to remove traces of Ru byproducts.

General procedure for the glyoxylic acid condensation/ borohydride reduction approach to $\beta$-substituted butenolides:

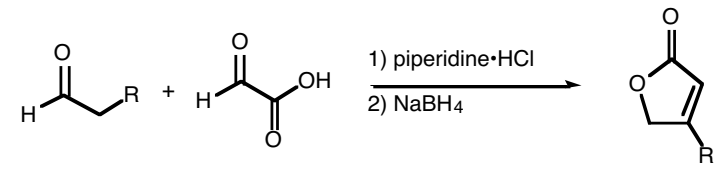

This procedure is as described in the literature, with the exception that commercially available piperidine hydrochloride was used in place of morpholine hydrochloride. ${ }^{2}$ Glyoxylic acid monohydrate (1.05 equiv) and piperidine hydrochloride (1.1 equiv) were added to a solution of aldehyde (1 equiv) in 7/1 mixture of dioxane and water ( $2 \mathrm{M}$ in aldehyde) and the mixture was refluxed for $16 \mathrm{~h}$. The mixture was cooled to ambient temperature and $10 \% \mathrm{HCl}$ was added. The solution was extracted four times with ethyl acetate, the organic layers were combined, washed with brine, dried over $\mathrm{Na}_{2} \mathrm{SO}_{4}$, filtered and concentrated to dryness. The residue was dissolved in $\mathrm{MeOH}(1.5 \mathrm{~mL} / \mathrm{mmol}$ of aldehyde) and sodium borohydride ( $4 \mathrm{H}^{-}$equiv) was added portion-wise to the rapidly stirred solution. After $2 \mathrm{~h}$, the reaction mixture was treated with $10 \% \mathrm{HCl}$ and extracted three times with ethyl acetate. The organic layers were combined, washed with brine, dried over $\mathrm{MgSO}_{4}$, filtered and concentrated to dryness. The residue was purified by flash chromatography.

4-Butyl-5H-furan-2-one (10a).

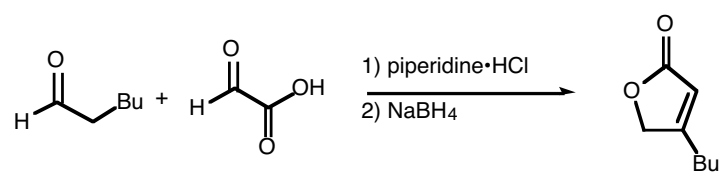

2 (a) Bourguignon, J.J.; Wermuth, C.G. J. Org. Chem. 1981, 46, 4889. (b) Bourguignon, J.J.; Schoenfelder, A.; Schmitt, M.; Wermuth, C.G.; Hechler, V.; Charlier, B.; Maitre, M. J. Med. Chem. 1988, $31,893$. 
Hexanal $(6.0 \mathrm{~mL}, 49.9 \mathrm{mmol})$ was subjected to the glyoxylic acid condensation/ reduction protocol. The reaction mixture was purified by flash chromatography (30\% ethyl acetate/ hexanes) to afford the title compound as a colorless liquid (3.50 g, $50 \%)$. The ${ }^{1} \mathrm{H}$ NMR spectra was in accord with a literature report. ${ }^{3}$

4-Isoropyl-5H-furan-2-one (10b).

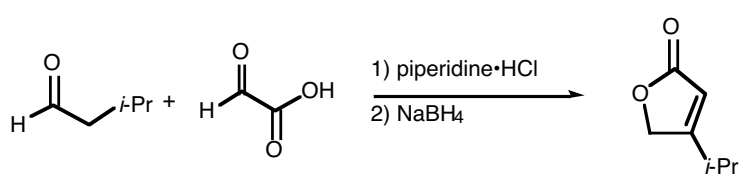

Isovaleraldehyde $(5.0 \mathrm{~mL}, 46.6 \mathrm{mmol})$ was subjected to the glyoxylic acid condensation/ reduction protocol. The reaction mixture was purified by flash chromatography (25\% ethyl acetate/ hexanes) to afford the title compound as a colorless liquid (1.50 g, 26\%). The ${ }^{1} \mathrm{H}$ NMR spectra was in accord with a literature report. ${ }^{4}$

4-Benzyl-5H-furan-2-one (6b).

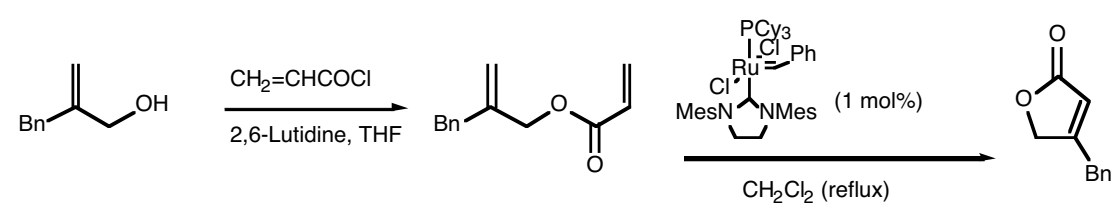

2-Benzyl-2-propen-1-ol ${ }^{5}(3.80 \mathrm{~g}, 25.6 \mathrm{mmol})$ was subjected to the general conditions for the esterification of allylic alcohols. The reaction mixture was purified by flash chromatography ( $5 \%$ ether/ hexane) to afford $\mathbf{5 b}$ as a colorless liquid (3.42 g, $66 \%)$ which was used directly in the next step.

Acrylate $5 \mathbf{b}$ (3.41 g, $16.9 \mathrm{mmol}$ ) was submitted to the general RCM procedure. The reaction mixture was purified by flash chromatography (35\% ethyl acetate/ hexanes) to yield a light purple oil. Kugelrohr distillation afforded the title compound as a colorless liquid (2.33 g, 79\%). The ${ }^{1} \mathrm{H}$ NMR spectra was in accord with a literature report. ${ }^{6}$

\section{4-(3,4-Dimethoxy-benzyl)-5H-furnan-2-one (8c).}

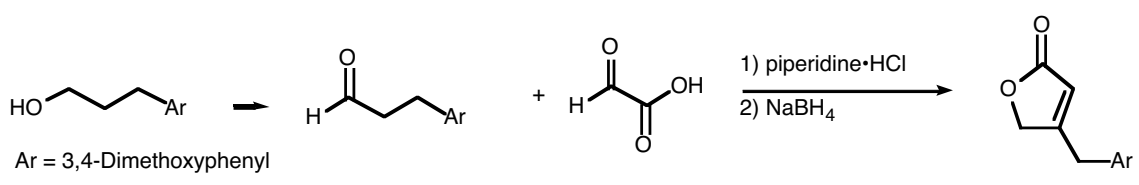

${ }^{3}$ Pelletier, S.W.; Djarmati, Z.; Laj_i_, S.D.; Mi_ovi_, I.V.; Yang, D.T.C. Tetrahedron 1975, $31,1659$.

${ }^{4}$ McMorris, T.C.; Chavez, R. G.; Patil, P. A., J.Chem.Soc.,Perkin Trans.1 1996, 295.

5 Buboudin, J.G.; Jousseaume, B. J. Organomet. Chem. 1979, 168, 1.

${ }^{6}$ Bella, M.; Piancatelli, G.; Pigro, M. C., Tetrahedron 1999, 55,12387. 
$4 \AA ̊$ Molecular seives $(1.5 \mathrm{~g})$ were added to a $23{ }^{\circ} \mathrm{C}$ solution of 3-(3,4-dimethoxyphenyl)-propan-1-ol (2.78 $\mathrm{mL}, 15.3$ mmol) in $\mathrm{CH}_{2} \mathrm{Cl}_{2}(50 \mathrm{~mL})$. After $30 \mathrm{~min}$, pyrindinium chlorochromate $(4.94 \mathrm{~g}, 22.9 \mathrm{mmol})$ was added. After $1 \mathrm{~h}$, the mixture was filtered through a pad of celite and silica gel and concentrated to dryness to afford $2.46 \mathrm{~g}$ of $\mathbf{8 c}$ as a pale yellow liquid (83\%). This material was used directly in the next step.

The glyoxylic acid condensation/ reduction protocol was applied to aldehyde 8c (2.46 g, 12,7 mmol) to afford the title compound as a crystalline solid after purification by flash chromatography (60\% ethyl acetate/ hexanes) (2.35 g, $79 \%)$. $\mathrm{Mp}\left(\mathrm{CH}_{2} \mathrm{Cl}_{2}\right): 53-54{ }^{\circ} \mathrm{C} ;{ }^{1} \mathrm{H}$ NMR $\left(300 \mathrm{MHz}, \mathrm{CDCl}_{3}\right) \delta: 3.69$ (s, 2H), 3.87 (s, 3H), $3.88(\mathrm{~s}, 3 \mathrm{H}), 4.71-4.74(\mathrm{~m}, 2 \mathrm{H}), 4.72$ (quint, $J=1 \mathrm{~Hz}, 1 \mathrm{H}), 6.67(\mathrm{AB}, \mathrm{d}, J=1.5 \mathrm{~Hz}, 1 \mathrm{H}), 6.73(\mathrm{ABX}, \mathrm{dd}, J=8,1.5 \mathrm{~Hz}, 1 \mathrm{H}), 6.84(\mathrm{AB}, \mathrm{d}, J=8 \mathrm{~Hz}, 1 \mathrm{H}) ;{ }^{13} \mathrm{C}$

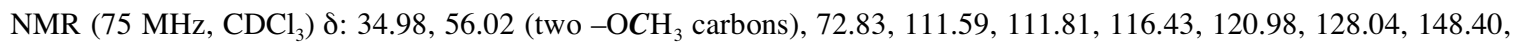
149.37, 169.64, 173.90; IR (cm $\left.{ }^{-1}\right): 1741,1513,1451$; Anal. Calcd. for $\mathrm{C}_{13} \mathrm{H}_{14} \mathrm{O}_{4}: \mathrm{C}, 66.66 ; \mathrm{H}, 6.02$. Found: C, 66.40; H, 5.99.

4-Phenyl-5H-furan-2-one (6c).

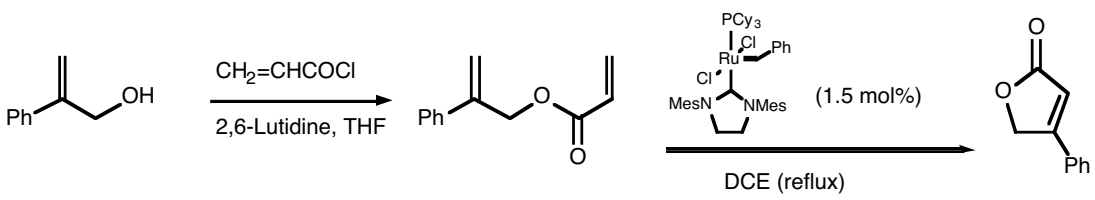

2-Phenyl-2-propen-1-ol ${ }^{5}(3.80 \mathrm{~g}, 25.6 \mathrm{mmol})$ was subjected to the general procedure for the esterification of allyic alcohols with acryloyl chloride except that toluene was used in place of THF as solvent. The reaction mixture was purified by flash chromatography (5\% ether/ hexanes) to afford acrylate $\mathbf{5 c}$ as a colorless liquid (3.42 g, $66 \%)$. This material was used directly in the next step.

The general RCM protocol was applied to $5 \mathbf{c}(1.55 \mathrm{~g}, 8.23 \mathrm{mmol})$, except that $1.5 \mathrm{~mol} \%$ of 7 was used instead of 1 mol\%, and the reaction was conducted in refluxing $\mathrm{ClCH}_{2} \mathrm{CH}_{2} \mathrm{Cl}(10 \mathrm{~mL})$ in stead of $\mathrm{CH}_{2} \mathrm{Cl}_{2}$. The residue obtained by concentration of the reaction mixture was stirred vigorously in ether and $700 \mathrm{mg}$ of product was filtered off as a pale brown solid. Concentration of the mother liquors and purification by flash chromatography (30\% ethyl acetate/ hexanes) afforded a further $160 \mathrm{mg}$ of product. This was combined with the material isolated by filtration and subjected to Kugelrohr distillation to afford the desired product as a white crystalline solid (850 mg, $64 \%)$. $\mathrm{Mp}\left(\mathrm{Et}_{2} \mathrm{O}\right)$ : 85-88 ${ }^{\circ} \mathrm{C}$. The ${ }^{1} \mathrm{H}$ NMR spectra was in accord with a literature report. ${ }^{2 b}$

\section{4-Methyl-5,6-dihydro-pyran-2-one (6d).}




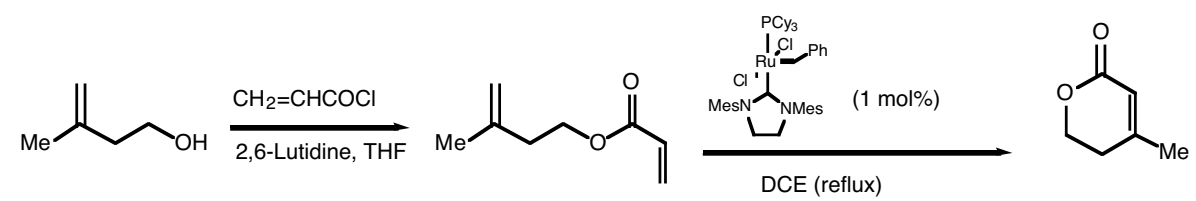

3-Methyl-3-buten-1-ol $(5.9 \mathrm{~mL}, 58.1 \mathrm{mmol})$ was subjected to the conditions for the esterification of homoallylic alcohols except that ether was used in place of THF as solvent. The reaction mixture was purified by flash chromatography (5\% ether/ hexanes) to afford acrylate $\mathbf{5 d}$ as a colorless liquid (3.64 g, $45 \%$ ).

The general conditions for RCM was applied to $\mathbf{5 d}(2.00 \mathrm{~g}, 14.3 \mathrm{mmol})$. The reaction mixture was purified by flash chromatography (40\% ethyl acetate/ hexanes) to afford the title compound as a light purple oil which was subjected to Kugelrohr distillation to yield a colorless product (1.23 g, $76 \%$ ). The ${ }^{1} \mathrm{H}$ NMR spectra was in accord with a literature report. $^{7}$

4-Propyl-5,6-dihydro-pyran-2-one (12a).
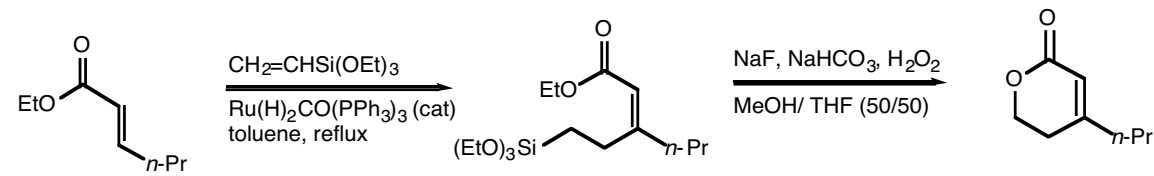

Triethoxyvinyl silane $(11.5 \mathrm{~mL}, 54.5 \mathrm{mmol})$ and $11 \mathrm{a}(3.87 \mathrm{~g}, 27.2 \mathrm{mmol})$ were added via syringe to a solution of $(\mathrm{CO}) \mathrm{Ru}(\mathrm{H})_{2}\left(\mathrm{Ph}_{3} \mathrm{P}\right)_{3}(500 \mathrm{mg}, 0.545 \mathrm{mmol})$ in toluene $(25 \mathrm{~mL})$. The reaction was warmed to $80{ }^{\circ} \mathrm{C}$ and stirred under an Ar atmosphere for 36 hours. GC analysis of the crude reaction mixture indicated the product was formed as a mixture of $Z$ and $E$ double bond isomers, present in a ratio of $4.9: 1$. The reaction mixture was concentrated to dryness and the residue was dissolved in a $1: 1$ mixture of $\mathrm{MeOH} / \mathrm{THF}(100 \mathrm{~mL})$. Sodium bicarbonate (4.54 g, $54 \mathrm{mmol})$, sodium fluoride (11.3 g, $270 \mathrm{mmol})$ and hydrogen peroxide $(34 \mathrm{~mL}, 540 \mathrm{mmol}, 30 \%$ aqueous $)$ were added. After $24 \mathrm{~h}$, the reaction mixture was added to $10 \%$ aqueous sodium sulfite (Caution! Mild exotherm observed). The aqueous layer was extracted four times with ethyl acetate. The organic layers were combined, washed with brine, dried over $\mathrm{MgSO}_{4}$, filtered and concentrated to dryness. Pyridinium $p$-toluenesulfonate $(10 \mathrm{mg})$ was added and the mixture was placed in a $110{ }^{\circ} \mathrm{C}$ oil bath for $1 \mathrm{~h}$. The mixture was then purified by flash chromatography (30\% ethyl acetate/ hexanes) to afford the title compound as a colorless oil (828 mg, $22 \%)$, along with non-lactonized material (646 mg, $14 \%)$ as a 1.2 $: 1(Z: E)$ mixture of double bond isomers. The ${ }^{1} \mathrm{H}$ NMR spectra of 12a was in accord with a literature report. ${ }^{8}$

\section{4-Cyclohexyl-5,6-dihydro-pyran-2-one (12b).}

7 Fernandes, R. A.; Kumar, P. Tetrahedron: Asymmetry 1999, 10, 4349.

${ }^{8}$ Kato, M.; Ouchi, A.; Yoshikoshi, A. Bull.Chem.Soc.Jpn. 1991, 64, 1479. 

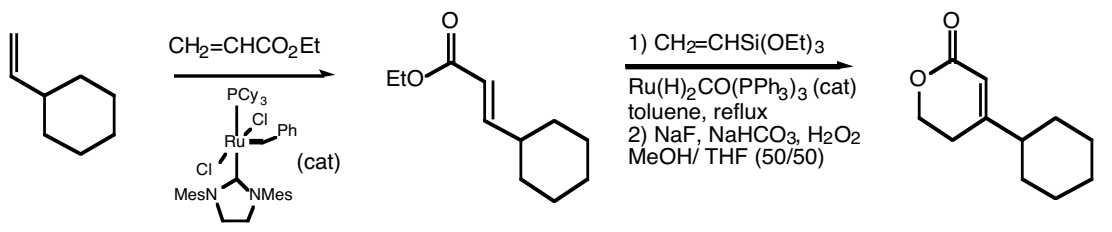

Vinyl cyclohexane $(3.7 \mathrm{~mL}, 27 \mathrm{mmol})$ and ethyl acrylate $(5.9 \mathrm{~mL}, 54 \mathrm{mmol})$ were added to a solution of 7 (231 $\mathrm{mg}$, $0.272 \mathrm{mmol})$ in $\mathrm{CH}_{2} \mathrm{Cl}_{2}(40 \mathrm{~mL})$ and the mixture was refluxed for $3 \mathrm{~h}$. The mixture was concentrated to dryness and purified by flash chromatography (5\% ether/ hexanes) to yield $\mathbf{1 1 b}$ as a colorless liquid $(4.22 \mathrm{~g} \mathrm{~g}, 85 \%)$. This material was used directly in the next step.

A solution of $\mathbf{1 1 b}(497 \mathrm{mg}, 2.72 \mathrm{mmol})$ in toluene $(5 \mathrm{~mL})$ was added to a solution of triethoxyvinylsilane $(1.1 \mathrm{~mL}, 5.4$ $\mathrm{mmol})$ and $(\mathrm{CO}) \mathrm{Ru}(\mathrm{H})_{2}\left(\mathrm{Ph}_{3} \mathrm{P}\right)_{3}(250 \mathrm{mg}, 0.272 \mathrm{mmol})$ in toluene. The mixture was refluxed for $12 \mathrm{~h}$, then cooled to room temperature and concentrated to dryness. The residue was purified by flash chromatography ( $5 \%$ ether/ hexanes) to yield the silane as a pale yellow liquid ( $556 \mathrm{mg}, 55 \%)$. This material was used directly in the next step.

$30 \%$ Aqueous $\mathrm{H}_{2} \mathrm{O}_{2}(1.0 \mathrm{~mL}, 16.1 \mathrm{mmol})$ was added to a mixture of the silane prepared in the previous step (600 mg, $1.61 \mathrm{mmol}), \mathrm{NaF}(169 \mathrm{mg}, 4.03 \mathrm{mmol})$ and $\mathrm{NaHCO}_{3}(135 \mathrm{mg}, 1.61 \mathrm{mmol})$ in a $1: 1(\mathrm{v} / \mathrm{v})$ mixture of $\mathrm{MeOH}$ and $\mathrm{THF}$ $(6 \mathrm{~mL})$. After $24 \mathrm{~h}$, the mixture was partitioned between ethyl acetate and $10 \% \mathrm{HCl}$. The aqueous layer was extracted two times with ethyl acetate, the organic layers were combined, washed with brine, dried over $\mathrm{MgSO}_{4}$, filtered and concentrated to dryness. PPTS $\left(10 \mathrm{mg}\right.$ ) was added and the residue was warmed to $115^{\circ} \mathrm{C}$ for $30 \mathrm{~min}$, then was purified by flash chromatography (30\% ethyl acetate/ hexanes) to afford the title compound as a colorless oil (260 mg, $90 \%)$.

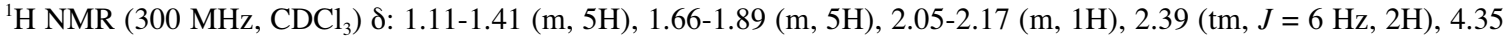

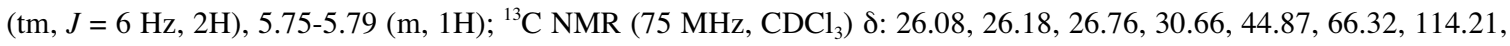
165.45, 166.25, 202.31; Anal. Calcd. for $\mathrm{C}_{11} \mathrm{H}_{16} \mathrm{O}_{2}$ : C, 73.30; H, 8.95. Found: C, 73.03; H, 9.04.

\section{4-Butyl-1,5-dihydro-pyrrol-2-one (14a).}

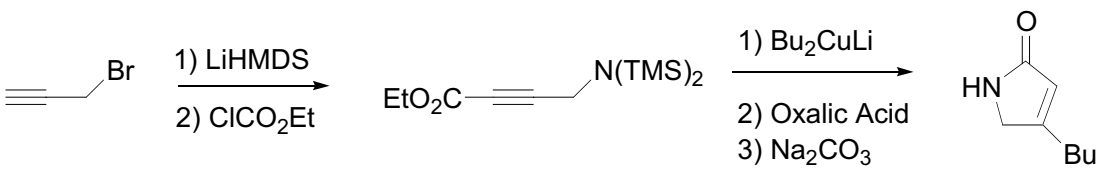

This substrate was prepared using a slight modification of a literature procedure. ${ }^{9}$ Propargyl bromide $(16.1 \mathrm{~mL}$ of an $80 \%$ solution in toluene, $145 \mathrm{mmol}$ ) was added to a $-30{ }^{\circ} \mathrm{C}$ suspension of LiHMDS (56.3 $\left.\mathrm{g}, 336 \mathrm{mmol}\right)$ in ether (Caution! Due to heat of solvation, ether will reflux on addition to LiHMDS and the solids should be cooled before 
adding solvent). The mixture was allowed to warm to $23{ }^{\circ} \mathrm{C}$ over $4 \mathrm{~h}$, then cooled to $-30{ }^{\circ} \mathrm{C}$. Ethylchloroformate (13.9 $\mathrm{mL}, 145 \mathrm{mmol}$ ) was added and the mixture was allowed to warm to $23{ }^{\circ} \mathrm{C}$ over $18 \mathrm{~h}$. The reaction mixture was filtered though a pad of celite and concentrated to dryness. The residue was suspended in pentane and filtered through celite a second time. The filtrate was concentrated to dryness and the residue was purified by vacuum distillation $(0.1 \mathrm{~mm} \mathrm{Hg})$ with the aid of a $10 \mathrm{~cm}$ Vigroux column. The material boiling above $90{ }^{\circ} \mathrm{C}$ was collected to afford $21.0 \mathrm{~g}$ (53\% yield) of a clear liquid which slowly turned brown on standing. GC analysis showed the material to be $97 \%$ pure.

n-BuLi (8.01 mL, 2.30 M in hexane, $18.4 \mathrm{mmol})$ was added to a $-40{ }^{\circ} \mathrm{C}$ suspension of $\mathrm{CuI}(3.51 \mathrm{~g}, 18.4 \mathrm{mmol})$ in ether $(80 \mathrm{~mL})$. After $5 \mathrm{~min}$, the resulting brown suspension was cooled to $-78{ }^{\circ} \mathrm{C}$ and a solution of ethyl 4 (bistrimethylsilylamino)but-2-ynoate $(5.20 \mathrm{~g}, 19.1 \mathrm{mmol})$ in ether $(20 \mathrm{~mL})$ was added. The mixture was allowed to warm to $-50{ }^{\circ} \mathrm{C}$ for $3 \mathrm{~h}$. The mixture was cooled back to $-70{ }^{\circ} \mathrm{C}$ and $\mathrm{MeOH}(5 \mathrm{~mL})$ was added. The mixure was warmed to ambient temperature and filtered though a pad of celite. The filtrate was concentrated to dryness and the residue was dissolved in acetone $(30 \mathrm{~mL})$. Saturated oxalic acid $(30 \mathrm{~mL})$ was added and the acetone was removed on a rotory evaporator. The residue was neutralized with saturated sodium carbonate and extracted three times with ether. The organic layers were combined, washed with brine, dried over $\mathrm{MgSO}_{4}$, filtered and concentrated to dryness. The residue was dissolved in $10 \%$ ether/ hexane and placed in a $0{ }^{\circ} \mathrm{C}$ fridge. After $16 \mathrm{~h}$, the suspension was filtered to afford the desired product as a pale green solid (974 mg, 38\%). A further $730 \mathrm{mg}(28 \%)$ was isolated after flash chromatography $\left(5 \% \mathrm{MeOH} / \mathrm{CH}_{2} \mathrm{Cl}_{2}\right)$. The ${ }^{1} \mathrm{H}$ NMR spectra was in accord with a literature report. ${ }^{7}$

\section{4-Butyl-1-(4-Methoxy-phenyl)-1,5-dihyro-pyrrol-2-one (14b).}

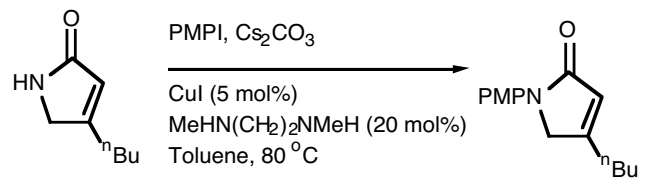

Lactam 14a (400 mg, $2.87 \mathrm{mmol}), \mathrm{CuI}(27.4 \mathrm{mg}, 0.144 \mathrm{mmol}), \mathrm{Cs}_{2} \mathrm{CO}_{3}(1.22 \mathrm{~g}, 5.75 \mathrm{mmol})$, and 4-iodoanisole (1.01 g, $4.31 \mathrm{mmol}$ ) were added to a flask which was evacuated and charged with a nitrogen atmosphere. $N, N^{\prime}$ Dimethylethylenediamine $(61 \mu \mathrm{L}, 0,575 \mathrm{mmol})$ and toluene $(2.5 \mathrm{~mL})$ were added and the mixture was warmed to $60{ }^{\circ} \mathrm{C}$ for $2 \mathrm{~h}$. The reaction was cooled to ambient temperature and filtered through a plug of silica gel which was washed with ethyl acetate. The filtrate was concentrated to dryness and the residue was purified by flash chromatography ( $40 \%$ EtOAc/ Hexane) to afford the title compound as a crystalline solid $(620 \mathrm{mg}, 88 \%) . \quad \mathrm{Mp}\left(\mathrm{Et}_{2} \mathrm{O}\right): 74-78{ }^{\circ} \mathrm{C} ;{ }^{1} \mathrm{H} \mathrm{NMR}$ $\left(300 \mathrm{MHz}, \mathrm{CDCl}_{3}\right) \delta: 0.95(\mathrm{t}, J=7 \mathrm{~Hz}, 3 \mathrm{H}), 1.40$ (hextet, $\left.J=7.5 \mathrm{~Hz}, 2 \mathrm{H}\right), 1.59$ (quintet, $\left.J=7.5 \mathrm{~Hz}, 2 \mathrm{H}\right), 2.41(\mathrm{t}, J=$ $7.5 \mathrm{~Hz}, 2 \mathrm{H}), 3.79(\mathrm{~s}, 3 \mathrm{H}), 4.26(\mathrm{~s}, 2 \mathrm{H}), 5.91(\mathrm{~d}, J=1 \mathrm{~Hz}, 1 \mathrm{H}), 6.88(\mathrm{AB}, \mathrm{d}, J=9 \mathrm{~Hz}, 2 \mathrm{H}), 7.54(\mathrm{AB}, \mathrm{d}, J=9 \mathrm{~Hz}, 2 \mathrm{H})$;

\footnotetext{
${ }^{9}$ Corriu, R.J.P.; Bolin, G.; Iqbal, J.; Moreau, J.J.E; Vernhet, C. Tetrahedron 1993, 49, 4603.
} 
${ }^{13} \mathrm{C}$ NMR $\left(75 \mathrm{MHz}, \mathrm{CDCl}_{3}\right) \delta: 14.13,22.67,29.56,30.02,55.50,55.71,114.31,120.73,122.92,132.67,156.07$, 159.05, 170.58; IR (film, $\mathrm{cm}^{-1}$ ): 1681, 1513, 1443, 1380, 1266; Anal. Calcd. for $\mathrm{C}_{15} \mathrm{H}_{19} \mathrm{NO}_{2}$ : C, 73.44; H, 9.81; N, 5.71. Found: C, 73.14; H, 7.76; N, 5.67.

4-Methyl-1-(4-Methoxy-phenyl)-1,5-dihyro-pyrrol-2-one (13).

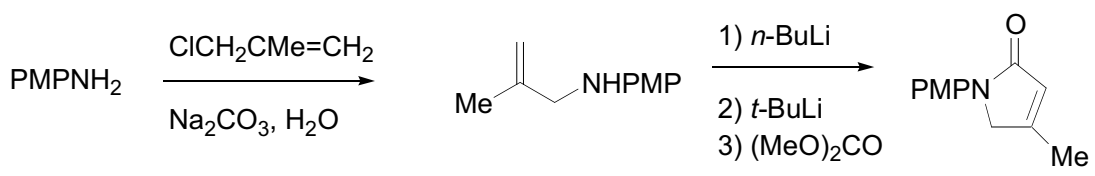

Methodology used in the synthesis of the $N$-phenyl analogue analogue of $\mathbf{1 3}$ was employed. ${ }^{10}$ Methallyl chloride (50.3 mmol) was added to a mixture of $p$-anisidine $(5.00 \mathrm{~g}, 40.6 \mathrm{mmol})$ and $\mathrm{K}_{2} \mathrm{CO}_{3}(2.80 \mathrm{~g}, 20.3 \mathrm{mmol})$ in water $(35 \mathrm{~mL})$ and the resulting mixture was refluxed for three hours open to the air. The mixture was cooled to ambient temperature and extracted three times with ethyl acetate. The organic layers were combined, washed with brine, dried over $\mathrm{MgSO}_{4}$, filtered and concentrated to dryness. The residue was purified by flash chromatography (10\% ethyl acetate/ hexanes) to afford methallylated $p$-anisidine $(3.79 \mathrm{~g}, 53 \%)$ as a pale yellow liquid. ${ }^{1} \mathrm{H} \mathrm{NMR}\left(300 \mathrm{MHz}, \mathrm{CDCl}_{3}\right) \delta: 1.77(\mathrm{~s}, 3 \mathrm{H})$, $3.62\left(\mathrm{~s}, 3 \mathrm{H}\left(\mathrm{CH}_{2} \mathrm{~N}\right.\right.$ and $\left.\mathrm{NH}\right), 3.73(\mathrm{~s}, 3 \mathrm{H}), 4.85(\mathrm{~s}, 1 \mathrm{H}), 4.94(\mathrm{~s}, 1 \mathrm{H}), 6.56(\mathrm{AB}, \mathrm{d}, J=9 \mathrm{~Hz}, 2 \mathrm{H}), 6.75(\mathrm{AB}, \mathrm{d}, J=9 \mathrm{~Hz}$, $2 \mathrm{H}) ;{ }^{13} \mathrm{C} \mathrm{NMR}\left(75 \mathrm{MHz}, \mathrm{CDCl}_{3}\right) \delta: 20.86,51.06,56.02,110.95,114.14,114.89,132.54,143.15,151.98 ; \mathrm{IR}$ (film, $\mathrm{cm}^{-}$ $\left.{ }^{1}\right)$ : 3409, 1511, 1441, 1231; Anal. Calcd. for $\mathrm{C}_{11} \mathrm{H}_{15} \mathrm{NO}$ C, 74.54; H, 8.53; N, 7.90. Found: C, 74.12; H, 8.49; N, 7.83.

n-BuLi $\left(4.90 \mathrm{ml}, 2.30 \mathrm{M}\right.$ in hexanes, $11.3 \mathrm{mmol}$ ) was added to a $-30{ }^{\circ} \mathrm{C}$ solution of $N$-methallylated $p$-anisidine prepared above $(2.00 \mathrm{~g}, 11.3 \mathrm{mmol})$ in diethyl ether $(50 \mathrm{~mL})$. After $5 \mathrm{~min}$, the reaction mixture was warmed to ambient temperature. After $10 \mathrm{~min}$, the reaction was cooled to $-30{ }^{\circ} \mathrm{C}$ and $t$-BuLi $(11.3 \mathrm{~mL}, 1.50 \mathrm{M}$ in pentane, $16.9 \mathrm{mmol})$ was added. After $10 \mathrm{~min}$, the mixture was warmed to ambient temperature for $30 \mathrm{~min}$, then cooled to $-30{ }^{\circ} \mathrm{C}$. Dimethylcarbonate $(951 \mu \mathrm{L}, 11.3 \mathrm{mmol})$ was added and after 10 min the reaction mixture was warmed to ambient temperature. After $15 \mathrm{~h}$, the mixture was treated with water and extracted three times with ethyl acetate. The organic layers were combined, washed with brine, dried over $\mathrm{MgSO}_{4}$, filtered and concentrated to dryness. The residue was purified by flash chromatography ( $70 \%$ ethyl acetate/ hexanes) to afford the title compound as a white crystalline solid

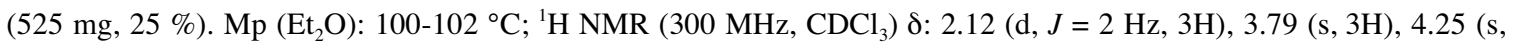
2H), 5.93 (sextet, $J=1.5 \mathrm{~Hz}, 1 \mathrm{H}), 6.88(\mathrm{AB}, \mathrm{d}, J=9 \mathrm{~Hz}, 2 \mathrm{H}), 7.53(\mathrm{AB}, \mathrm{d}, J=9 \mathrm{~Hz}, 2 \mathrm{H}) ;{ }^{13} \mathrm{C} \mathrm{NMR}\left(75 \mathrm{MHz}, \mathrm{CDCl}_{3}\right)$ ঠ: $15.52,55.65,56.54,114.24,120.68,123.97,132.56,154.37,156.00,170.50 ;$ IR (film, $\left.\mathrm{cm}^{-1}\right)$ : 1671; Anal. Calcd. for $\mathrm{C}_{12} \mathrm{H}_{13} \mathrm{NO}_{2}$ : C, 70.92; H, 6.45; N, 6.89. Found: C, 70.63; H, 6.40; N, 6.87.

\section{4-Ethyl-1-(4-methoxy-phenyl)-5,6-dihydro-1H-pyridin-2-one (17).}




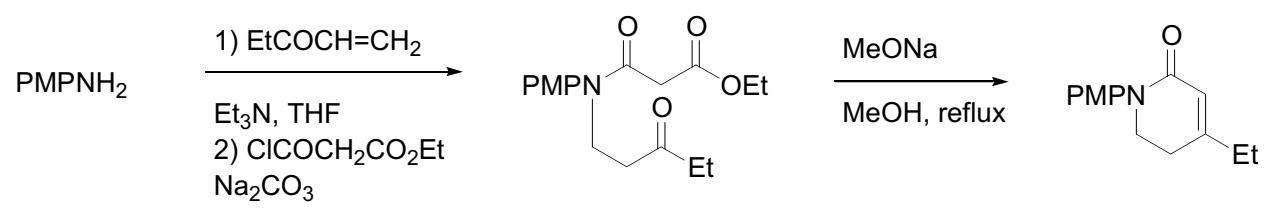

Ethyl vinylketone $(10.0 \mathrm{~mL}, 97.4 \mathrm{mmol})$ was added to a solution of $p$-anisidine $(10 \mathrm{~g}, 81.2 \mathrm{mmol})$ in $\mathrm{THF}(80 \mathrm{~mL})$ and the mixture was warmed to reflux for $18 \mathrm{~h}$. The solution was cooled to ambient temperature, equal parts water and brine were added, and the mixture was extracted two times with ethyl acetate. The organic layers were washed with brine, dried over $\mathrm{MgSO}_{4}$, filtered and concentrated to dryness. The residue was suspended in $15 \% \mathrm{Et}_{2} \mathrm{O} / \mathrm{hexanes}(100$ $\mathrm{mL})$, stirred for $30 \mathrm{~min}$, then filtered to afford the Michael addition product $\mathbf{1 6}$ as a pale grey solid $(9.34 \mathrm{~g}, 55 \%)$. A second and third crop yielded a further 2.37 and $1.93 \mathrm{~g}$ respectively for a total isolated yield of $13.64 \mathrm{~g}(81 \%)$. Mp (Et $2 \mathrm{O} /$ hexanes): $41-43{ }^{\circ} \mathrm{C} ;{ }^{1} \mathrm{H}$ NMR $\left(300 \mathrm{MHz}, \mathrm{CDCl}_{3}\right) \delta: 1.05$ (t, $\left.J=7.3 \mathrm{~Hz}, 3 \mathrm{H}\right), 3.79(\mathrm{q}, J=7.3 \mathrm{~Hz}, 2 \mathrm{H}), 2.69$ (t, $J$ $=6.2 \mathrm{~Hz}, 2 \mathrm{H}), 3.36(\mathrm{t}, J=6.2 \mathrm{~Hz}, 2 \mathrm{H}), 3.74(\mathrm{~s}, 3 \mathrm{H}), 6.58(\mathrm{AB}, \mathrm{d}, J=9 \mathrm{~Hz}, 2 \mathrm{H}), 6.77(\mathrm{AB}, \mathrm{d}, J=9 \mathrm{~Hz}, 2 \mathrm{H}) ;{ }^{13} \mathrm{C} \mathrm{NMR}$

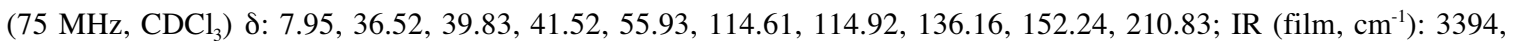
1708, 1511, 1235, 1036; Anal. Calcd. for $\mathrm{C}_{12} \mathrm{H}_{17} \mathrm{NO}_{2}: \mathrm{C}, 69.54 ; \mathrm{H}, 8.27$; N, 6.76. Found: C, 69.69; H, 8.24; N, 6.66.

Saturated $\mathrm{Na}_{2} \mathrm{CO}_{3}(10 \mathrm{~mL})$ was added to a solution of $\mathbf{1 6}(1.86 \mathrm{~g}, 8.97 \mathrm{mmol})$ and ethylmalonylchloride $(1.40 \mathrm{~mL}(90 \%$ pure), $9.87 \mathrm{mmol})$ in $\mathrm{CH}_{2} \mathrm{Cl}_{2}(20 \mathrm{~mL})$. After $30 \mathrm{~min}$, water was added and the mixture was extracted two times with $\mathrm{CH}_{2} \mathrm{Cl}_{2}$. The organic layers were washed with brine, filtered through cotton, and concentrated to dryness. The residue was dissolved in EtOH $(30 \mathrm{~mL})$. EtONa $(1.22 \mathrm{~g}, 17.9 \mathrm{mmol})$ was added and the mixture was stirred for $15 \mathrm{~min}$ at ambient temperature before powdered $\mathrm{KOH}(1.00 \mathrm{~g}, 17.9 \mathrm{mmol})$ was added and the mixture was heated to reflux for 18h. A 1:1 mixture of $10 \%$ hydrochloric acid and brine was added and the mixture was extracted four times with ethyl acetate. The organic layers were washed with brine, dried over $\mathrm{MgSO}_{4}$, filtered and concentrated to dryness. The residue was suspended in $\mathrm{Et}_{2} \mathrm{O}(25 \mathrm{~mL})$, stirred at $0^{\circ} \mathrm{C}$ for $30 \mathrm{~min}$, then filtered to afford the title compound as a white solid (1.31 g, 70\%). $\mathrm{Mp}\left(\mathrm{Et}_{2} \mathrm{O}\right): 96-98{ }^{\circ} \mathrm{C} ;{ }^{1} \mathrm{H} \mathrm{NMR}\left(300 \mathrm{MHz}, \mathrm{CDCl}_{3}\right) \delta: 1.14(\mathrm{t}, J=7.5 \mathrm{~Hz}, 3 \mathrm{H}), 2.26(\mathrm{q}, J=7.5 \mathrm{~Hz}$, 2H), $2.44(\mathrm{t}, J=7 \mathrm{~Hz}, 2 \mathrm{H}), 3.78(\mathrm{t}, J=7 \mathrm{~Hz}, 2 \mathrm{H}), 3.80(2,3 \mathrm{H}), 5.85(\mathrm{t}, J=1.4 \mathrm{~Hz}, 1 \mathrm{H}), 6.91(\mathrm{AB}, \mathrm{d}, J=9 \mathrm{~Hz}, 2 \mathrm{H})$, $7.21(\mathrm{AB}, \mathrm{d}, J=9 \mathrm{~Hz}, 2 \mathrm{H}) ;{ }^{13} \mathrm{C}\left(125 \mathrm{~Hz}, \mathrm{CDCl}_{3}\right) \delta: 11.34,28.94,29.60,49.01,55.62,114.18,119.24,126.44,135.75$, 156.59, 157.42, 165.04; IR (neat film, $\mathrm{cm}^{-1}$ ) 1667, 1623, 1511, 1239; Anal. Calcd. for $\mathrm{C}_{14} \mathrm{H}_{17} \mathrm{NO}_{2}$ : C, 72.70; $\mathrm{H}, 7.41$. Found: C, 72.58; H, 7.35.

\section{Enantioselective Conjugate Reductions}

\section{General procedure for the reduction of 5-membered lactones:}

\footnotetext{
${ }^{10}$ Barluenga, J.; Fañanás, F.J.; Foubelo, F.; Yus, M. Tetrahedron Lett. 1988, 29, 4859.
} 

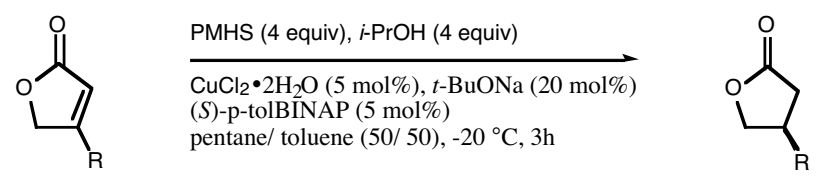

$\mathrm{CuCl}_{2} \cdot 2 \mathrm{H}_{2} \mathrm{O}(5 \mathrm{~mol} \%),(S)$-p-tolBINAP $(5 \mathrm{~mol} \%)$, and $t$-BuONa $(20 \mathrm{~mol} \%)$ were added to a Schlenk tube which was then evacuated and charged with an argon atmosphere. PMHS (4 equiv) and pentane $(1.5 \mathrm{~mL} / \mathrm{mmol}$ of lactone) were added and the mixture was stirred for $2 \mathrm{~h}$ before being cooled to $-20^{\circ} \mathrm{C}$. A solution of lactone ( 1 equiv), dodecane as an internal standard $(1 \mu \mathrm{L} / \mathrm{mg}$ of lactone), and $i-\mathrm{PrOH}$ (4 equiv) in toluene $(1.5 \mathrm{~mL} / \mathrm{mmol}$ of lactone) was added via syringe. The mixture was stirred until GC analysis revealed $>95 \%$ conversion of the substrate. The reaction mixture was partitioned between $10 \%$ hydrochloric acid and ethyl acetate. The aqueous layer was extracted two times with ethyl acetate. The organic layers were combined, washed with brine, dried over $\mathrm{MgSO}_{4}$, filtered and concentrated to dryness. The residue was purified by flash chromatography.

\section{General procedure for the reduction of 6-membered lactones:}
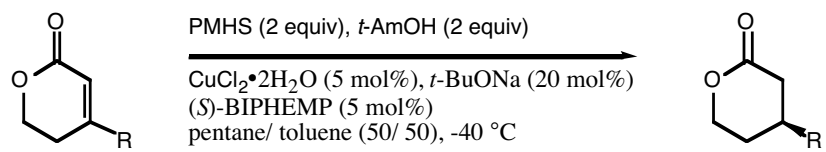

$\mathrm{CuCl}_{2} \cdot 2 \mathrm{H}_{2} \mathrm{O}(5 \mathrm{~mol} \%),(S)$-BIPHEMP (5 mol\%), and $t$-BuONa $(20 \mathrm{~mol} \%)$ were added to a Schlenk tube which was then evacuated and charged with an argon atmosphere. PMHS (2 equiv) and toluene $(0.75 \mathrm{~mL} / \mathrm{mmol}$ of lactone) were added via syringe and the mixture was stirred for $30 \mathrm{~min}$. Pentane $(1.5 \mathrm{~mL} / \mathrm{mmol}$ of lactone $)$ was added and the mixture was cooled to $-40{ }^{\circ} \mathrm{C}$. A solution of lactone (1 equiv) and dodecane as an internal standard $(1 \mu \mathrm{L} / \mathrm{mg}$ of lactone) in toluene $(0.75 \mathrm{~mL} / \mathrm{mmol}$ of lactone) was added via syringe, followed by $t$-AmOH ( 2 equiv). The mixture was stirred at $-40{ }^{\circ} \mathrm{C}$ until GC analysis showed $>95 \%$ conversion of the substrate. The reaction mixture was quenched by the addition of $10 \%$ hydrochloric acid. The aqueous layer was extracted three times with ether, the organic layers were combined, washed with brine, dried over $\mathrm{MgSO}_{4}$, filtered and concentrated to dryness. The residue was purified by flash chromatography.

\section{General procedure for the reduction of unsaturated lactams:}
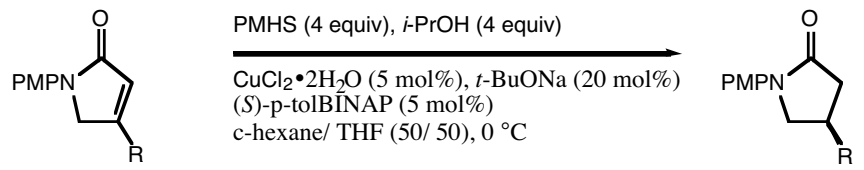

A solution of lactam (1 equiv) and $i$-PrOH (4 equiv) in THF $\left(0.75 \mathrm{~mL} / \mathrm{mmol}\right.$ of lactam) was added to a $0{ }^{\circ} \mathrm{C}$ slurry of $\mathrm{CuCl}_{2} \cdot 2 \mathrm{H}_{2} \mathrm{O}(5 \mathrm{~mol} \%),(S)$-p-tolBINAP (5 mol\%), $t$-BuONa (20 mol\%), and PMHS (4 equiv) in c-hexane $(0.75 \mathrm{~mL} /$ 
mmol of lactam) under nitrogen. The mixture was stirred at $0{ }^{\circ} \mathrm{C}$ until $\mathrm{GC}$ analysis showed $>95 \%$ conversion of the substrate. The reaction mixture was quenched by the addition of $10 \%$ hydrochloric acid. The aqueous layer was extracted three times with ethyl acetate, the organic layers were combined, washed with brine, dried over $\mathrm{MgSO}_{4}$, filtered and concentrated to dryness. The residue was purified by flash chromatography.

\section{4-Butyl-dihydro-furan-2-one.}

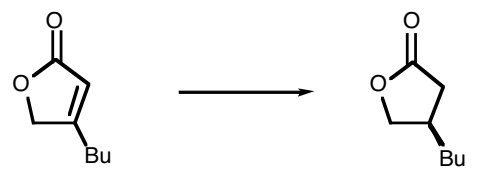

The general conditions for the reduction of 5-membered lactones ( $3 \mathrm{~h}$ reaction time) were applied to $\mathbf{1 0 a}(100 \mathrm{mg}$, $0.713 \mathrm{mmol})$. Purification by flash chromatography $(15 \rightarrow 20 \%$ ethyl acetate/ hexanes) afforded the title compound as an oil (90 mg, $89 \%$ yield). Chiral GC analysis (GTA column, $1 \mathrm{~mL} / \mathrm{min}, 90{ }^{\circ} \mathrm{C}, 60 \mathrm{~min}$, then $1{ }^{\circ} \mathrm{C} / \mathrm{min}$ to $120^{\circ} \mathrm{C}$, hold for $20 \mathrm{~min}$, retention times: $93.9 \mathrm{~min}$ (major), $95.5 \mathrm{~min}$ (minor)) showed $86 \%$ ee. $\quad \alpha_{\mathrm{D}}(589 \mathrm{~nm}, 38.5 \mathrm{mg} / \mathrm{mL}$ $\left.\mathrm{CHCl}_{3}\right)=+5$. The ${ }^{1} \mathrm{H}$ NMR spectra and $\alpha_{\mathrm{D}}$ were in accord with a literature report. ${ }^{11}$

\section{4-Isopropyl-dihydro-furan-2-one.}

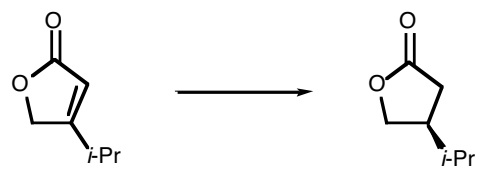

The general conditions for the reduction of 5-membered lactones ( $3 \mathrm{~h}$ reaction time) were applied to $\mathbf{1 0 b}(100 \mathrm{mg}$, $0.793 \mathrm{mmol})$. Purification by flash chromatography $(15 \rightarrow 30 \%$ ethyl acetate/ hexanes $)$ afforded the title compound as an oil $\left(89 \mathrm{mg}, 88 \%\right.$ yield). Chiral $\mathrm{GC}$ analysis (GTA column, $1 \mathrm{~mL} / \mathrm{min}, 90^{\circ} \mathrm{C}, 60 \mathrm{~min}$, then $1{ }^{\circ} \mathrm{C} / \mathrm{min}$ to $120^{\circ} \mathrm{C}$, hold for $20 \mathrm{~min}$, retention times: $92.1 \mathrm{~min}$ (major), $93.9 \mathrm{~min}$ (minor)) showed $92 \%$ ee. $\alpha_{\mathrm{D}}(589 \mathrm{~nm}, 10.0 \mathrm{mg} / \mathrm{mL}$ $\left.\mathrm{CHCl}_{3}\right)=12.7$. The ${ }^{1} \mathrm{H}$ NMR spectra and $\alpha_{\mathrm{D}}$ were in accord with a literature report. ${ }^{12}$

\section{4-Benzyl-dihydro-furan-2-one.}

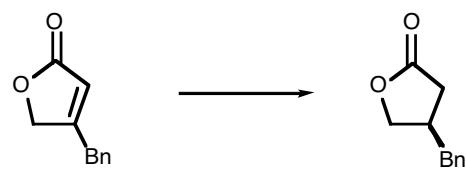

11 (a) Roeder, E.; Krauss, H. Liebigs Ann. Chem. 1992, 177. (b) Takahashi, A.; Kanna, H.; Uda, H. J. Chem. Soc., Perkin Trans. 1 1989, 935.

12 Koch, S. S. C.; Chamberlin, A. R., J.Org.Chem. 1993, 58, 2725. 
The general conditions for the reduction of 5-membered lactones ( $3 \mathrm{~h}$ reaction time) were applied to $\mathbf{6 b}$ (100 mg, 0.574 mmol). Purification by flash chromatography $(25 \rightarrow 30 \%$ ethyl acetate/ hexanes $)$ afforded the title compound as an oil (93 mg, $92 \%$ yield). Chiral HPLC analysis (Daicel Chiralpak® AD column $(0.46 \mathrm{~cm} \emptyset \times 25 \mathrm{~cm}), 1 \mathrm{~mL} / \mathrm{min}, 7 \% i$ $\mathrm{PrOH} / \mathrm{Hexane}$, retention times: $17.04 \mathrm{~min}$ (major), $18.62 \mathrm{~min}$ (minor)) showed $92 \%$ ee. $\quad \alpha_{\mathrm{D}}(589 \mathrm{~nm}, 19.9 \mathrm{mg} / \mathrm{mL}$ $\left.\mathrm{CHCl}_{3}\right)=+5.9$. The ${ }^{1} \mathrm{H}$ NMR spectra and $\alpha_{\mathrm{D}}$ were in accord with a literature report. ${ }^{13}$

\section{4-(3,4-Dimethoxy-benzyl)-dihydro-furan-2-one.}
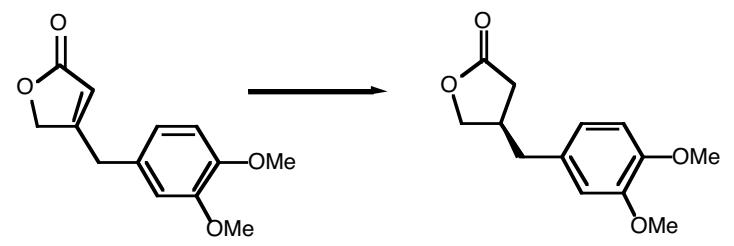

The general conditions for the reduction of 5-membered lactones ( $4.5 \mathrm{~h}$ reaction time), were applied to $10 \mathrm{c}$ (200 $\mathrm{mg}$, $0.854 \mathrm{mmol})$ except that dichloromethane $(0.7 \mathrm{~mL})$ was added to facilitate solvation of the starting material. Purification by flash chromatography (50\% ethyl acetate/ hexanes) afforded the title compound as a cloudy viscous oil (160 mg, $80 \%$ yield). Chiral HPLC analysis (Daicel Chiralpak® OB-H column $(0.46 \mathrm{~cm} \varnothing \times 25 \mathrm{~cm}), 0.75 \mathrm{~mL} / \mathrm{min}$, 35\% $i$-PrOH/ Hexane, retention times: 72.6 min (major), $89.1 \mathrm{~min}$ (minor)) showed $92 \%$ ee. $\quad \alpha_{\mathrm{D}}(589 \mathrm{~nm}, 26.4 \mathrm{mg} /$ $\left.\mathrm{mL} \mathrm{CHCl}_{3}\right)=+4.3$. The ${ }^{1} \mathrm{H}$ NMR spectra and $\alpha_{\mathrm{D}}$ were in accord with a literature report. ${ }^{14}$

\section{4-Phenyl-dihydro-furan-2-one.}
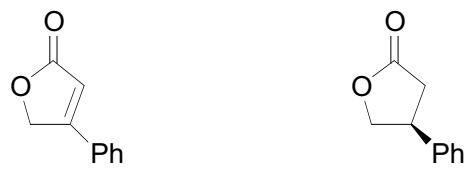

The general conditions for the reduction of 5-membered lactones were applied to $\mathbf{6 c}(100,0.624 \mathrm{mmol})$, except that $\mathrm{CH}_{2} \mathrm{Cl}_{2}(0.5 \mathrm{~mL})$ was added to facilitate the solvation of the starting material $(7 \mathrm{~h}$ reaction time). Purification by flash chromatography (35\% ethyl acetate/ hexanes) afforded the title compound as a crystalline solid (71 mg, $70 \%$ yield). Chiral GC analysis (GTA column, $1 \mathrm{~mL} / \mathrm{min}, 150{ }^{\circ} \mathrm{C}, 20 \mathrm{~min}$, retention times: $15.4 \mathrm{~min}$ (major), 15.9 min (minor)) showed $71 \%$ ee. Mp (ethyl acetate/ hexanes): $49-51{ }^{\circ} \mathrm{C} ; \alpha_{\mathrm{D}}\left(589 \mathrm{~nm}, 19.9 \mathrm{mg} / \mathrm{mL} \mathrm{CHCl}_{3}\right)=+37.2$. The ${ }^{1} \mathrm{H}$ NMR spectra, $\alpha_{\mathrm{D}}$, and melting point were in accord with a literature report. ${ }^{15}$

${ }^{13}$ (a) Heerden, P. S. van; Bezuidenhoudt, B. C. B.; Ferreira, D., Tetrahedron 1996, 52, 12313. (b) Caro, Y.; Masaguer, C. F.; Ravina, E., Tetrahedron: Asymmetry 2001, 12, 1723.

${ }^{14}$ Morimoto, T.; Chiba, M.; Achiwa, K., Tetrahedron 1993, 49, 1793.

15 (a) Takaya, Y.; Senda, T.; Kurushima, H.; Ogasawara, M.; Hayashi, T., Tetrahedron: Asymmetry 1999, 10, 4047. (b) Rizzacasa, M. A.; Sargent, M. V., J.Chem.Soc.,Perkin Trans.1, 1991, 845. 
4S-4-Methyl-tetrahydro-pyran-2-one.

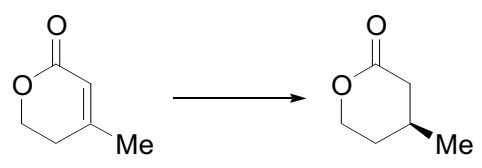

The general conditions for the reduction of 6-membered lactones ( $3 \mathrm{~h}$ reaction time) were applied to $6 \mathbf{d}$ (200 $\mathrm{mg}, 1.79$ mmol). Purification by flash chromatography (5\% ethyl acetate/ dichloromethane) afforded a mixture of the title compound and an unidentified by product $(160 \mathrm{mg}, 5: 1$ mixture). A second flash chromatography (80\% ethyl acetate/ hexanes) afforded the title compound as a colorless liquid (135 mg, $66 \%$ yield). Chiral GC analysis (GTA column, $1 \mathrm{~mL} / \mathrm{min}, 120^{\circ} \mathrm{C}, 20 \mathrm{~min}$, retention times: $15.71 \mathrm{~min}$ (major), $17.48 \mathrm{~min}$ (minor)) showed $82 \%$ ee. $\quad \alpha_{\mathrm{D}}(589$ $\left.\mathrm{nm}, 36.8 \mathrm{mg} / \mathrm{mL} \mathrm{CHCl}{ }_{3}\right)=-23.6$. The ${ }^{1} \mathrm{H}$ NMR spectra and $\alpha_{\mathrm{D}}$ were in accord with a literature report. ${ }^{16}$

\section{S-4-Propyl-tetrahydro-pyran-2-one.}

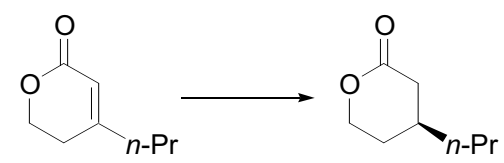

The general conditions for the reduction of 6-membered lactones ( $3 \mathrm{~h}$ reaction time) were applied to $\mathbf{1 2 a}$ (100 mg, $0.713 \mathrm{mmol})$. Purification by flash chromatography (25\% ethyl acetate/ hexanes) afforded a mixture of the title compound and an unidentified by product (160 mg, $5: 1$ mixture). A second flash chromatography (80\% ether/ hexanes) afforded the title compound as a colorless liquid (71 mg, $70 \%$ yield). Chiral GC analysis (GTA column, 1 $\mathrm{mL} / \mathrm{min}, 12{ }^{\circ} \mathrm{C}, 50 \mathrm{~min}$, retention times: $41.3 \mathrm{~min}$ (major), $46.2 \mathrm{~min}$ (minor)) showed $86 \%$ ee. $\alpha_{\mathrm{D}}(589 \mathrm{~nm}, 23.8 \mathrm{mg} /$ $\left.\mathrm{mL} \mathrm{CHCl}_{3}\right)=-21.4$. The ${ }^{1} \mathrm{H}$ NMR spectra and $\alpha_{\mathrm{D}}$ were in accord with a literature report. ${ }^{17}$

\section{S-4-Cyclohexyl-tetrahydro-pyran-2-one.}

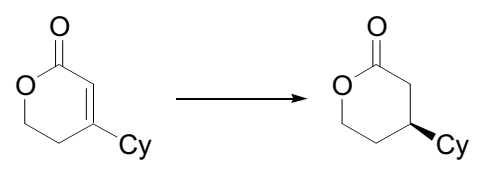

The general conditions for the reduction of 6-membered lactones (6 h reaction time) were applied to $\mathbf{1 2 b}$ ( $80 \mathrm{mg}, 0.44$ mmol). Purification by flash chromatography (25\% ethyl acetate/ hexanes) afforded a mixture of the title compound and an unidentified by product (65 mg, $8: 1$ mixture). A second flash chromatography ( $80 \%$ ether/ hexanes) afforded

${ }^{16}$ Nagao, Y.; Ikeda, T.; Inoue, T.; Yagi, M.; Shiro, M.; Fujita, E., J.Org.Chem. 1985, 50, 4072.

${ }^{17}$ (a) Kayser, M.M.; Chen, G.; Stewart, J.D. J. Org. Chem. 1998, 63, 7103. (b) Jones, J.B.; Lok, K.P. Can. J. Chem. 1979, 57, 1025. 
the title compound as a colorless liquid (44 mg, $55 \%$ yield). Chiral GC analysis (GTA column, $1 \mathrm{~mL} / \mathrm{min}, 150{ }^{\circ} \mathrm{C}, 50$ min, retention times: $37.3 \mathrm{~min}$ (major), $40.0 \mathrm{~min}$ (minor)) showed $94 \%$ ee. $\alpha_{\mathrm{D}}\left(589 \mathrm{~nm}, 30.6 \mathrm{mg} / \mathrm{mL} \mathrm{CHCl}_{3}\right)=+6$. The ${ }^{1} \mathrm{H}$ NMR spectra and $\alpha_{\mathrm{D}}$ were in accord with a literature report. ${ }^{17 \mathrm{~b}}$

4R-4-Methyl-1-(4-methoxy-phenyl)-pyrrolidin-2-one.

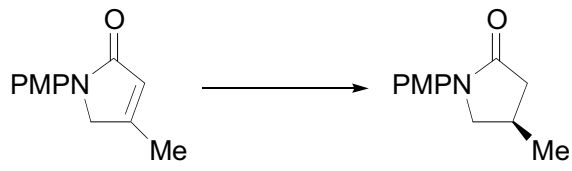

The general reduction conditions for unsaturated lactams (1 hour reaction time) were applied to 13 (50 mg, 0.267 mmol). Purification of the residue by flash chromatography (70\% ethyl acetate/ hexanes) afforded the title compound as a white crystalline solid $(48 \mathrm{mg}, 95 \%)$. Chiral HPLC analysis (Daicel Chiralpak ${ }^{\circledR}$ OB-H column $(0.46 \mathrm{~cm} \emptyset \times 25$ $\mathrm{cm}$ ), $0.5 \mathrm{~mL} / \mathrm{min}, 40 \%$ i-PrOH/ Hexane, 254, $280 \mathrm{~nm}$, retention times: 18.4 min (major), 24.4 min (minor)) showed 93\% ee. $\mathrm{Mp}\left(\mathrm{CH}_{2} \mathrm{Cl}_{2}\right): 49-51{ }^{\circ} \mathrm{C} ;{ }^{1} \mathrm{H} \mathrm{NMR}\left(500 \mathrm{MHz}, \mathrm{CDCl}_{3}\right) \delta: 1.20(\mathrm{~d}, J=6.8 \mathrm{~Hz}, 3 \mathrm{H}), 2.22(\mathrm{ABX}, \mathrm{dd}, J=16.7,7.4$ $\mathrm{Hz}, 1 \mathrm{H}), 2.55$ (octet, $J=7.4 \mathrm{~Hz}, 1 \mathrm{H}), 2.72(\mathrm{ABX}, \mathrm{dd}, J=16.7,8.4 \mathrm{~Hz}, 1 \mathrm{H}), 3.40(\mathrm{dd}, J=9.5,6.4 \mathrm{~Hz}, 1 \mathrm{H}), 3.79(\mathrm{~s}, 3 \mathrm{H})$, $3.90(\mathrm{dd}, J=9.5,7.6 \mathrm{~Hz}, 1 \mathrm{H}), 6.89(\mathrm{ABX}, \mathrm{dm}, J=9.1 \mathrm{~Hz}, 2 \mathrm{H}), 7.47(\mathrm{ABX}, J=9.1 \mathrm{~Hz}, 2 \mathrm{H}) ;{ }^{13} \mathrm{C} \mathrm{NMR}(75 \mathrm{MHz}$,

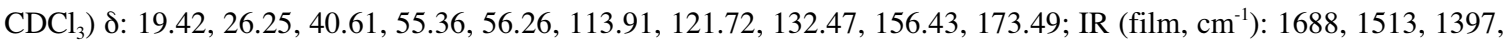
1266, 1034; Anal. Calcd. for $\mathrm{C}_{12} \mathrm{H}_{15} \mathrm{NO}_{2}$ : C, 70.22; H, 7.37. Found: C, 70.06; H, 7.31. $\alpha_{\mathrm{D}}(589 \mathrm{~nm}, 23.8 \mathrm{mg} / \mathrm{mL}$ $\left.\mathrm{CHCl}_{3}\right)=-4.2$.

4R-4-Butyl-1-(4-methoxy-phenyl)-pyrrolidin-2-one.

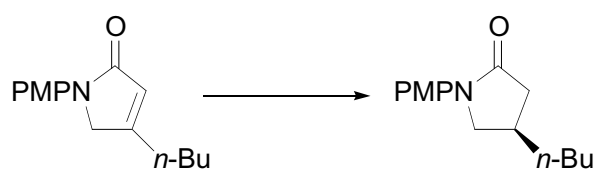

The general conditions for lactam reductions (three hour reaction time) were applied to $\mathbf{1 5}$ (78 $\mathrm{mg}, 0.318 \mathrm{mmol}$ ), except that toluene was used in place of THF. Purification by flash chromatography (10\% ethyl acetate/ dichloromethane) afforded the title compound as a white crystalline solid (74 mg, 94\%). Chiral HPLC analysis (Daicel Chiralpak® OB$\mathrm{H}$ column $(0.46 \mathrm{~cm} \varnothing \times 25 \mathrm{~cm}), 0.5 \mathrm{~mL} / \mathrm{min}, 40 \% i$-PrOH/ Hexane, $254 \mathrm{~nm}$, retention times: 11.4 min (major), 14.4 min (minor)) showed $94 \%$ ee. Mp (diethyl ether): $54-56{ }^{\circ} \mathrm{C} ;{ }^{1} \mathrm{H}$ NMR $\left(300 \mathrm{MHz}, \mathrm{CDCl}_{3}\right) \delta: 0.92(\mathrm{t}, J=7 \mathrm{~Hz}, 3 \mathrm{H})$, 1.29-1.41 (m, 4H), 1.48-1.58 (m, 2H), $2.28(\mathrm{ABX}, \mathrm{dd}, J=16.5,8 \mathrm{~Hz}, 1 \mathrm{H}), 2.46$ (heptet, $J=8 \mathrm{~Hz}, 1 \mathrm{H}), 2.70(\mathrm{ABX}, \mathrm{dd}$, $J=16.5,8 \mathrm{~Hz}, 1 \mathrm{H}), 3.42(\mathrm{ABX}, \mathrm{dd}, J=9.5,6.5 \mathrm{~Hz}, 1 \mathrm{H}), 3.80(\mathrm{~s}, 3 \mathrm{H}), 3.86(\mathrm{t}, J=9.5 \mathrm{~Hz}, 1 \mathrm{H}), 6.90(\mathrm{AB}, \mathrm{d}, J=9 \mathrm{~Hz}$ 2H), $7.48(\mathrm{AB}, \mathrm{d}, J=9 \mathrm{~Hz}, 2 \mathrm{H}) ;{ }^{13} \mathrm{C} \mathrm{NMR}\left(75 \mathrm{MHz}, \mathrm{CDCl}_{3}\right) \delta: 14.20,22.86,31.85,34.44,36.08,39.37,55.10,55.63$, 
114.21, 121.93, 132.87, 156.68, 173.66; Anal. Calcd. for $\mathrm{C}_{15} \mathrm{H}_{21} \mathrm{NO}_{2}: \mathrm{C}, 72.84 ; \mathrm{H}, 8.56$. Found: C, 72.58; $\mathrm{H}, 8.53 . \alpha_{D}$ $\left(589 \mathrm{~nm}, 10.1 \mathrm{mg} / \mathrm{mL} \mathrm{CHCl}_{3}\right)=+5$.

4S-4-Ethyl-1-(4-methoxy-phenyl)-piperidin-2-one.

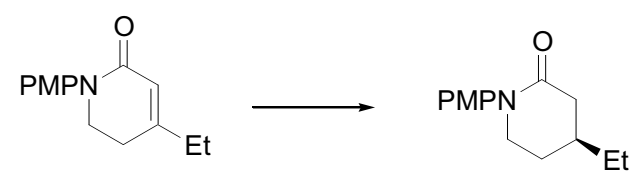

The general conditions for lactam reduction (30 min reaction time) were applied to 17 (100 $\mathrm{mg}, 0.432 \mathrm{mmol})$. The residue was purified by flash chromatography ( $70 \%$ ethyl acetate/ hexanes) to afford the title compound as a white solid (90 mg, 89\%). Chiral HPLC analysis (Daicel Chiralpak ${ }^{\circ}$ OJ column $(0.46 \mathrm{~cm} \varnothing \times 25 \mathrm{~cm}), 1.0 \mathrm{~mL} / \mathrm{min}, 15 \% i$ $\mathrm{PrOH} / \mathrm{Hexane}, 254 \mathrm{~nm}, 280 \mathrm{~nm}$, retention times: 13.4 min (major), 15.4 min (minor)) showed 91\% ee. Mp (diethyl ether): 58-60 ${ }^{\circ} \mathrm{C} ;{ }^{1} \mathrm{H}$ NMR $\left(300 \mathrm{MHz}, \mathrm{CDCl}_{3}\right.$ ) $\delta: 0.97(\mathrm{t}, J=7.4 \mathrm{~Hz}, 3 \mathrm{H}), 1.42$ (quintet, $\left.J=7.2 \mathrm{~Hz}, 2 \mathrm{H}\right), 1.53-1.69$ (m, 1H), 1.79-1.95 (m, 1H), 1.97-2.06 (m, 1H), $2.02(\mathrm{ABX}, \mathrm{dd}, J=17.3,10.7 \mathrm{~Hz}, 1 \mathrm{H}), 2.68$ (ABX, ddd, $J=17.6,5.2,2.2$ $\mathrm{Hz}, 1 \mathrm{H}), 3.53-3.70(\mathrm{~m}, 2 \mathrm{H}), 3.80(\mathrm{~s}, 3 \mathrm{H}), 6.90(\mathrm{AB}, \mathrm{d}, J=9 \mathrm{~Hz}, 2 \mathrm{H}), 7.14(\mathrm{AB}, \mathrm{d}, J=9 \mathrm{~Hz}, 2 \mathrm{H}) ;{ }^{13} \mathrm{C} \mathrm{NMR}(75 \mathrm{MHz}$, $\left.\mathrm{CDCl}_{3}\right) \delta: 11.35,28.67,29.31,34.94,39.14,51.24,55.51,114.40,127.32,135.97,157.91,169.92 ;$ IR (neat film, $\left.\mathrm{cm}^{-1}\right)$ : 1644, 1607, 1511, 1246; Anal. Calcd. for $\mathrm{C}_{14} \mathrm{H}_{19} \mathrm{NO}_{2}$ : C, 72.07; H, 8.21. Found: C, 72.10; H, 8.45; $\alpha_{\mathrm{D}}(589 \mathrm{~nm}, 10.1$ $\left.\mathrm{mg} / \mathrm{mL} \mathrm{CHCl}{ }_{3}\right)=-39.4$

\section{Reduction of 18 using low catalyst loading.}

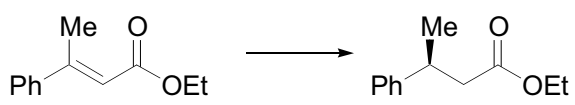

(S)-p-tolBINAP $(5.0 \mathrm{mg}, 0.00738 \mathrm{mmol}), \mathrm{CuCl}_{2}(1.0 \mathrm{mg}, 0.00738 \mathrm{mmol})$ and $t$-BuONa $(1.7 \mathrm{mg}, 0.0148 \mathrm{mmol})$ were added to a Schlenk tube which was evacuated and back filled with Ar. The mixture was suspended in c-hexane $(1 \mathrm{~mL})$ and transferred via canula to another Schlenk tube containing PMHS (1.77 mL, $29.5 \mathrm{mmol})$ and c-hexane (15 mL). 18 $(1.35 \mathrm{~mL}, 7.38 \mathrm{mmol})$ and $t-\mathrm{AmOH}(3.23 \mathrm{~mL} ., 29.5, \mathrm{mmol})$ were then added. After $36 \mathrm{~h}$, the mixture was poured into $1 \mathrm{~N} \mathrm{HCl}$, which was then extracted two times with ether. The organic layers were combined, washed with brine, and dried over $\mathrm{MgSO}_{4}$, filtered and concentrated to dryness. The residue was purified by flash chromatography (3\% ether/ hexanes) to afford ethyl-(S)-phenylbutanoate as a colorless liquid $(1.19 \mathrm{~g}, 90 \%)$ in $86 \%$ ee. HPLC analysis was performed as described by us previously. ${ }^{18}$ The ${ }^{1} \mathrm{H}$ NMR spectra was in accord with our previous report. ${ }^{18}$

\section{Kinetic Studies}




\section{Study of Reduction rates with different alcohols.}

A $15 \mathrm{~mL}$ Schlenk tube was charged with $(S)$ - $p$-tolBINAP $(10.0 \mathrm{mg}, 0.015 \mathrm{mmol}), \mathrm{CuCl}_{2}(2.0 \mathrm{mg}, 0.015 \mathrm{mmol})$ and $t$ BuOK (3.3 mg, $0.030 \mathrm{mmol})$. The vessel was evacuated and purged with argon before PMHS (716 $\mu \mathrm{L}, 12 \mathrm{mmol})$ and $c$-hexane $(2 \mathrm{~mL})$ were added. After stirring for $30 \mathrm{~min}$, a solution of $18(540 \mu \mathrm{L}, 3.0 \mathrm{mmol})$ and dodecane $(300 \mu \mathrm{L})$ in c-hexane $(3 \mathrm{~mL})$ was added. Each alcohol $(12 \mathrm{mmol})$ was added via syringe pump over $60 \mathrm{~min}$. Small aliquots were withdrawn periodically and the percent conversion was assessed by GC analysis.

\section{Synthesis of (-)-Paroxetine}

1-(4-Fluoro-phenyl)-3-(4-methoxy-phenylamino)-propan-1-one (19).

$\mathrm{PMPNH}_{2}$

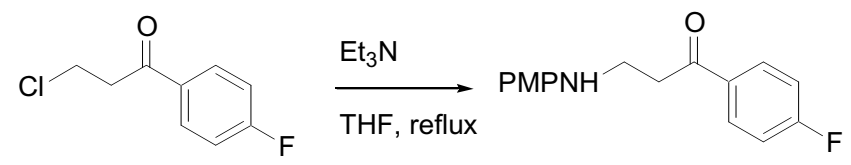

Triethyl amine $(18.1 \mathrm{~mL}, 0.129 \mathrm{mmol})$ was added to a solution of $p$-anisidine $(14.6 \mathrm{~g}, 0.119 \mathrm{~mol})$ and 3-chloropropio4'-fluorophenone ( $20 \mathrm{~g}, 0.108 \mathrm{~mol})$ in THF (100 mL) and the mixture was warmed to reflux for $4 \mathrm{~h}$. The mixture was cooled to ambient temperature and water was added. The mixture was extracted twice with ethyl acetate, the organic layers were combined, washed with brine, dried over $\mathrm{MgSO}_{4}$, filtered and concentrated to dryness. The residue was suspended in $\mathrm{Et}_{2} \mathrm{O}(50 \mathrm{~mL})$ and stirred for $30 \mathrm{~min}$. Filtration afforded the title compound as a pale grey/ green solid (22.7 g, 77\%). $\mathrm{Mp}\left(\mathrm{Et}_{2} \mathrm{O}\right): 107-108{ }^{\circ} \mathrm{C} ;{ }^{1} \mathrm{H} \mathrm{NMR}\left(300 \mathrm{MHz}, \mathrm{CDCl}_{3}\right) \delta: 3.23(\mathrm{t}, J=6 \mathrm{~Hz}, 2 \mathrm{H}), 3.55(\mathrm{t}, J=6 \mathrm{~Hz}, 2 \mathrm{H})$, $3.73(\mathrm{~s}, 3 \mathrm{H}), 3.83(\mathrm{bs}, 1 \mathrm{H}), 6.61(\mathrm{ABX}, \mathrm{dt}, J=9,2.5 \mathrm{~Hz}, 2 \mathrm{H}), 6.76(\mathrm{AB}, \mathrm{d}, J=9,2.5 \mathrm{~Hz}, 2 \mathrm{H}), 7.11(\mathrm{tt}, J=8.5,2 \mathrm{~Hz}$, 2H), $7.95(\mathrm{dd}, J=9,5 \mathrm{~Hz}, 2 \mathrm{H}) ;{ }^{13} \mathrm{C} \mathrm{NMR}\left(75 \mathrm{MHz}, \mathrm{CDCl}_{3}\right) \delta: 37.82,40.01,55.95,114.05,114.65,115.82(\mathrm{~d}, J=22$ $\mathrm{Hz}), 130.71(\mathrm{~d}, J=9 \mathrm{~Hz}), 133.21(\mathrm{~d}, J=3 \mathrm{~Hz}), 141.83,152.30,165.79(\mathrm{~d}, 254 \mathrm{~Hz}), 197.69$; IR (neat film, $\left.\mathrm{cm}^{-1}\right): 3390$, 1677, 1596, 1513; Anal. Calcd. for $\mathrm{C}_{15} \mathrm{H}_{14} \mathrm{FNO}_{2}$ : C, 70.58; H, 5.55; N, 5.14. Found: C, 70.32; H, 5.91; N, 5.20.

4-(4-Fluoro-phenyl)-1-(4-methoxy-phenyl)-5,6-dihydro-1H-pyridin-2-one (21).

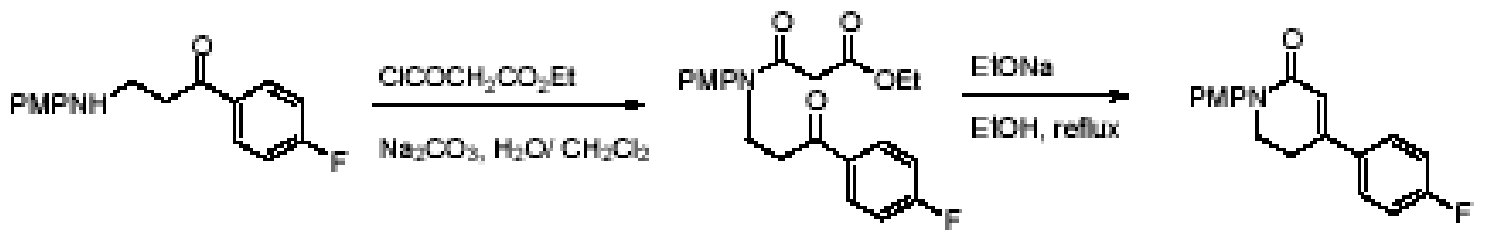

Saturated sodium carbonate $(50 \mathrm{~mL})$ was added to a solution of $19(10.00 \mathrm{~g}, 36.6 \mathrm{mmol})$ and ethyl 3-chloro-3oxopropionate $(5.15 \mathrm{~mL}, 40.2 \mathrm{mmol}$, tech grade, $\sim 90$ pure $)$ in $\mathrm{CH}_{2} \mathrm{Cl}_{2}(100 \mathrm{~mL})$. After $30 \mathrm{~min}$, water was added. The

${ }^{18}$ Appella, D. H.; Moritani, Y.; Shintani, R.; Ferreira, E. M.; Buchwald, S. L. J. Am. Chem. Soc. 1999, 121, 
aqueous layer was extracted three times with $\mathrm{CH}_{2} \mathrm{Cl}_{2}$, the organic layers were combined, washed with brine, filtered through cotton and concentrated to dryness. The residue was dissolved in EtOH $(100 \mathrm{~mL})$ and EtONa $(9.96 \mathrm{~g}, 146$ mmol) was added. After $15 \mathrm{~min}$, the mixture was warmed to reflux for $30 \mathrm{~min}$. The mixture was cooled to ambient temperature and poured into water. The resulting mixture was placed in an ice bath, stirred for 30 min and then filtered. The cake was suspended in toluene $(100 \mathrm{~mL})$, which was then concentrated to dryness to afford the title compound as a pale grey solid $(8.36 \mathrm{~g}, 77 \%)$. ${ }^{1} \mathrm{H}$ NMR showed the material to be contaminated with $\sim 5 \%$ of the $\beta, \gamma-$ unsaturated isomer. $\mathrm{Mp}$ (toluene): $138-142{ }^{\circ} \mathrm{C} ;{ }^{1} \mathrm{H} \mathrm{NMR}\left(300 \mathrm{MHz}, \mathrm{CDCl}_{3}\right) \delta: 2.91(\mathrm{t}, J=7 \mathrm{~Hz}, 2 \mathrm{H}), 3.82(\mathrm{~s}, 3 \mathrm{H})$, $3.94(\mathrm{t}, J=7 \mathrm{~Hz}, 2 \mathrm{H}), 6.40(\mathrm{~s}, 1 \mathrm{H}), 2.94(\mathrm{AB}, \mathrm{d}, J=9 \mathrm{~Hz}, 2 \mathrm{H}), 7.12(\mathrm{t}, J=9 \mathrm{~Hz}, 2 \mathrm{H}), 7.26(\mathrm{AB}, \mathrm{d}, J=9 \mathrm{~Hz}, 2 \mathrm{H}), 7.55$ $(\mathrm{dd}, J=9,5 \mathrm{~Hz}, 2 \mathrm{H}) ;{ }^{13} \mathrm{C}$ NMR $\left(75 \mathrm{MHz}, \mathrm{CDCl}_{3}\right) \delta 27.15,48.56,55.91,114.18,115.90(\mathrm{~d}, 20 \mathrm{~Hz}), 122.03,126.35$, $128.09(\mathrm{~d}, J=8 \mathrm{~Hz}), 133.84(\mathrm{~d}, J=3 \mathrm{~Hz}), 135.55,148.71,157.79,163.89(\mathrm{~d}, J=248 \mathrm{~Hz}), 165.34$; IR (neat film, $\left.\mathrm{cm}^{-1}\right)$ : 1648, 1603, 1511, 1229; Anal. Calcd. for $\mathrm{C}_{18} \mathrm{H}_{16} \mathrm{FNO}_{2}$ : C, 72.71; H, 5.42. Found: C, 72.72; H, 5.41.

4R-4-(4-Fluoro-phenyl)-1-(4-methoxy-phenyl)-piperidin-2-one (22).
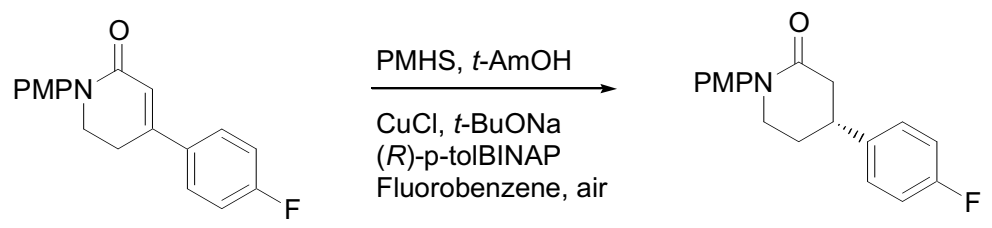

$\mathrm{CuCl}_{2}(13.3 \mathrm{mg}, 0.0992 \mathrm{mmol})$ and $t$-BuONa $(19.1 \mathrm{mg}, 0.198 \mathrm{mmol})$ were added to a mixture of $21(1.18 \mathrm{~g}, 3.97$ mmol), $(R)$ - $p$-tolBINAP (13.5 mg, $0.0198 \mathrm{mmol})$, PMHS $(3.81 \mathrm{~mL}, 63.5 \mathrm{mmol} \mathrm{H}$ ) and $t$-AmOH $(6.95 \mathrm{~mL}, 63.5 \mathrm{mmol})$ in fluorobenzene $(8 \mathrm{~mL})$. After $45 \mathrm{~min}, 10 \%$ hydrochloric acid was added and the mixture was extracted three times with ethyl acetate. The organic layers were combined, washed with brine, and dried over $\mathrm{MgSO}_{4}$, filtered and concentrated to dryness. The residue was purified by flash chromatography $(60 \rightarrow 100 \%$ ethyl acetate/ hexanes $)$ to afford the title compound as a crystalline solid (1.00 g, 89\%, based on 95\% pure starting material). Chiral HPLC analysis (Daicel Chiralpak ${ }^{\circledR}$ OD column $(0.46 \mathrm{~cm} \varnothing \times 25 \mathrm{~cm}), 1.0 \mathrm{~mL} / \mathrm{min}, 25 \% i$-PrOH/ Hexane, retention times: 19.4 $\min$ (minor), $22.3 \mathrm{~min}$ (major)) showed $90 \%$ ee. $\mathrm{Mp}\left(\mathrm{Et}_{2} \mathrm{O}\right): 183-186{ }^{\circ} \mathrm{C} ;{ }^{1} \mathrm{H}$ NMR $\left(300 \mathrm{MHz}, \mathrm{CDCL}_{3}\right) \delta: 2.02-2.27$ (m, 2H), $2.64(\mathrm{ABX}, \mathrm{dd}, J=17,11 \mathrm{~Hz}, 1 \mathrm{H}), 2.86(\mathrm{ABX}, \mathrm{ddd}, J=17,5,2 \mathrm{~Hz}, 1 \mathrm{H}), 3.18-3.30$ (m, 1H), $6.62(\mathrm{ABX}, \mathrm{ddd}$, $J=12,5,4 \mathrm{~Hz}, 1 \mathrm{H}), 3.68-3.83(\mathrm{~m}, 1 \mathrm{H}), 3.80(\mathrm{~s}, 3 \mathrm{H}), 6.92(\mathrm{ABX}, \mathrm{dt}, J=9,2 \mathrm{~Hz}, 2 \mathrm{H}), 7.03(\mathrm{tt}, J=9,2 \mathrm{~Hz}, 2 \mathrm{H}), 7.16$ $(\mathrm{AB}, \mathrm{dt}, J=9,2 \mathrm{~Hz}, 2 \mathrm{H}), 7.21(\mathrm{ABX}, \mathrm{dd}, J=9,5.5 \mathrm{~Hz}, 2 \mathrm{H}) ;{ }^{13} \mathrm{C} \mathrm{NMR}\left(75 \mathrm{MHz}, \mathrm{CDCl}_{3}\right) \delta: 30.98,38.31,40.21$, 51.06, 55.64, 114.61, $115.65(\mathrm{~d}, J=19 \mathrm{~Hz}), 127.41,128.01(\mathrm{~d}, J=8 \mathrm{~Hz}), 135.74,139.08(\mathrm{~d}, J=3 \mathrm{~Hz}), 158.19,161.60$ (d, $J=244 \mathrm{~Hz}$ ), 169.16; IR (neat film, $\mathrm{cm}^{-1}$ ): 1642, 1511, 1266; Anal. Calcd. for $\mathrm{C}_{18} \mathrm{H}_{18} \mathrm{FNO}_{2}$ : C, $72.22 ; \mathrm{H}, 6.06$. Found: C, 72.22; H, 6.05. $\alpha_{\mathrm{D}}\left(589 \mathrm{~nm}, 12.8 \mathrm{mg} / \mathrm{mL} \mathrm{CHCl}_{3}\right)=+8$.

9473. 
3S,4R-4-(4-Fluoro-phenyl)-1-(4-methoxy-phenyl)-2-oxo-piperidin-3-carboxylic acid methyl ester (23).
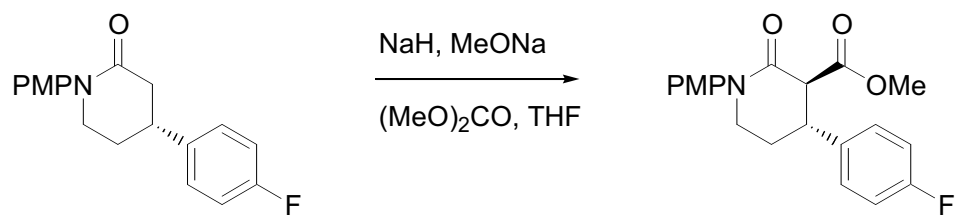

$\mathrm{MeOH}(889 \mu \mathrm{L}, 21.9 \mathrm{mmol})$ was added dropwise to a room temperature mixture of $22(2.19 \mathrm{~g}, 7.32 \mathrm{mmol})$ and sodium hydride (1.76 g, $43.9 \mathrm{mmol}, 60 \%$ suspension) in toluene $(40 \mathrm{~mL})$. Dimethyl carbonate $(1.85 \mathrm{~mL}, 21.9 \mathrm{mmol})$ was then added and the mixture was warmed to reflux for $4 \mathrm{~h}$. The reaction mixture was poured slowly into water and the resulting mixture was extracted three times with ethyl acetate. The organic layers were combined, washed with brine, dried over $\mathrm{MgSO}_{4}$, filtered and concentrated to dryness. The residue was purified by flash chromatography $(40 \rightarrow 50 \%$ ethyl acetate/ hexanes) to afford the title compound as a white solid $(2.07 \mathrm{~g}, 79 \%) . \quad \mathrm{Mp}\left(\mathrm{CH}_{2} \mathrm{Cl}_{2} /\right.$ hexanes): $119-124{ }^{\circ} \mathrm{C}$;

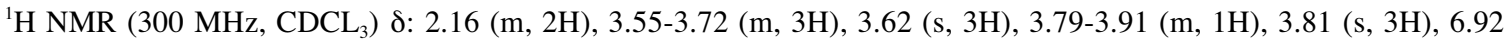
$(\mathrm{AB}, \mathrm{dt}, J=9,2 \mathrm{~Hz}, 2 \mathrm{H}), 7.04(\mathrm{tt}, J=9,2 \mathrm{~Hz}, 2 \mathrm{H}), 7.20(\mathrm{AB}, \mathrm{dt}, J=9,2 \mathrm{~Hz}, 2 \mathrm{H}), 7.23(\mathrm{ABX}, \mathrm{dd}, J=9,5 \mathrm{~Hz}, 2 \mathrm{H})$; ${ }^{13} \mathrm{C}$ NMR $\left(75 \mathrm{MHz}, \mathrm{CDCl}_{3}\right) \delta 30.06,41.08,50.96,52.36,56.01,57.74,114.32,116.02(\mathrm{~d}, 24 \mathrm{~Hz}), 127.10,128.19(J=$ $10 \mathrm{~Hz}), 134.85,136.94$ (d, $J=3 \mathrm{~Hz}), 158.21,162.03$ (d, $J=241 \mathrm{~Hz}), 165.83,170.23$; IR (neat film, $\left.\mathrm{cm}^{-1}\right): 1742,1652$; ; Anal. Calcd. for $\mathrm{C}_{20} \mathrm{H}_{20} \mathrm{FNO}_{4}$ : C, 67.22; H, 5.64. Found: C, 67.50; H, 5.59. $\alpha_{\mathrm{D}}\left(589 \mathrm{~nm}, 19.0 \mathrm{mg} / \mathrm{mL} \mathrm{CHCl}_{3}\right)=-$ 11.6.

\section{[4R,3S-4-(4-fluoro-phenyl)-1-(4-methoxy-phenyl)-piperidin-3-yl]-methanol (24).}
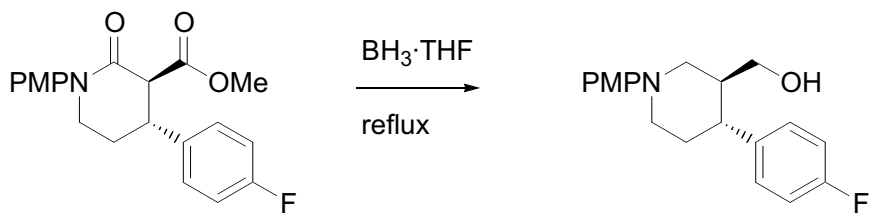

Borane (43.4 mL of a 1M THF solution, $43.4 \mathrm{mmol})$ was added to a flask containing 23 (1.94 g, $5.43 \mathrm{mmol})$. The resulting solution was refluxed for $18 \mathrm{~h}$, then cooled to ambient temperature and poured slowly into $1 \mathrm{M} \mathrm{NaOH}$. The mixture was extracted three times with ethyl acetate, the organic layers were washed with brine, dried over $\mathrm{MgSO}_{4}$, filtered and concentrated to dryness. The residue was purified by flash chromatography ( $50 \%$ ethyl acetate/ hexanes) to afford the title compound as a white solid (1.68 g, 98\%). $\mathrm{Mp}\left(\mathrm{Et}_{2} \mathrm{O}\right): 94-98{ }^{\circ} \mathrm{C} ;{ }^{1} \mathrm{H} \mathrm{NMR}\left(300 \mathrm{MHz}, \mathrm{CDCL}_{3}\right) \delta: 1.10-$ $1.20(\mathrm{~m}, 1 \mathrm{H}), 1.84-2.04(\mathrm{~m}, 2 \mathrm{H}), 2.05-2.19(\mathrm{~m}, 1 \mathrm{H}), 2.43(\mathrm{td}, J=11,5 \mathrm{~Hz}, 1 \mathrm{H}), 2.59(\mathrm{t}, J=11 \mathrm{~Hz}, 1 \mathrm{H}), 2.71(\mathrm{td}, J=$ $11,3 \mathrm{~Hz}, 1 \mathrm{H}), 3.30(\mathrm{dt}, J=11,7 \mathrm{~Hz}, 1 \mathrm{H}), 3.46(\mathrm{ABX}, \mathrm{dt}, J=11,4 \mathrm{~Hz}, 1 \mathrm{H}), 3.59(\mathrm{ABX}, \mathrm{dm}, J=11 \mathrm{~Hz}, 1 \mathrm{H}) ; 3.77(\mathrm{~s}$, 3H), 3.81 (ABX, ddd, $J=12,4,2 \mathrm{~Hz}, 1 \mathrm{H}), 6.84(\mathrm{ABX}, \mathrm{dt}, J=9,2 \mathrm{~Hz}, 2 \mathrm{H}), 6.97$ (ABX, dt, $J=9,2 \mathrm{~Hz}, 2 \mathrm{H}), 6,99$

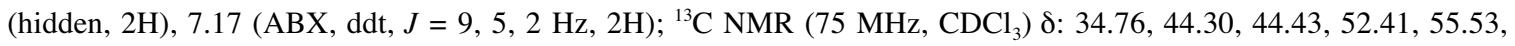
55.76, 63.91, 114.47, $115.52(\mathrm{~d}, J=21 \mathrm{~Hz}), 119.15,128.83(\mathrm{~d}, J=8 \mathrm{~Hz}), 139.83(\mathrm{~d}, J=3 \mathrm{~Hz}), 146.07,153.90,161.47$ 
(d, $J=244 \mathrm{~Hz}$ ); IR (neat film, $\mathrm{cm}^{-1}$ ): 3361; ; Anal. Calcd. for $\mathrm{C}_{19} \mathrm{H}_{22} \mathrm{FNO}_{2}: \mathrm{C}, 72.36 ; \mathrm{H}, 7.03$. Found: C, 72.30; $\mathrm{H}$, 7.07. $\left.\alpha_{\mathrm{D}}(589 \mathrm{~nm}, 9.8 \mathrm{mg} / \mathrm{mL} \mathrm{CHCl})_{3}\right)=-12.2$.

$(3 R, 4 S)$-trans- $N$-tert-Butoxycarbonyl-4-(4'-fluorophenyl)-3-hydroxymethylpiperidine (26).
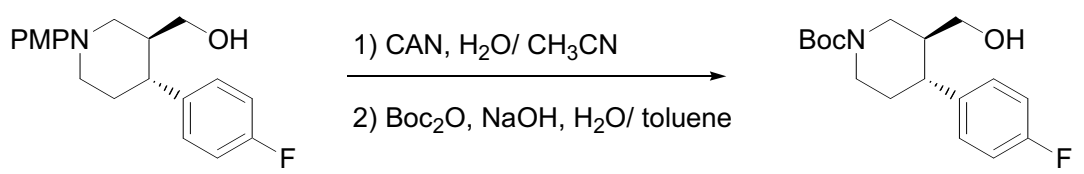

Ceric ammonium nitrate $(2.45 \mathrm{~g}, 4.48 \mathrm{mmol})$ was added to a solution of $\mathbf{2 4}$ (353 $\mathrm{mg}, 1.12 \mathrm{mmol})$ in a $3: 1 \mathrm{mixture}$ of $\mathrm{CH}_{3} \mathrm{CN} / \mathrm{H}_{2} \mathrm{O}(28 \mathrm{~mL})$ at ambient temperature. After $30 \mathrm{~min}, \mathrm{NaOH}(1 \mathrm{M})$ was added and the mixture was extracted four times with $\mathrm{CH}_{2} \mathrm{Cl}_{2}$. The organic layers were combined, washed with brine, filtered through cotton and concentrated to dryness. Di-tert-butyl carbonate $(489 \mathrm{mg}, 2.24 \mathrm{mmol})$ was added to the residue and the resulting mixture was dissolved in a 2:1 mixture of toluene/ $\mathrm{H}_{2} \mathrm{O}(6 \mathrm{~mL})$. Sodium hydroxide $(270 \mu \mathrm{L}, 25 \mathrm{wt} \%, 1.68 \mathrm{mmol})$ was added and the mixture was stirred at ambient temperature for $3 \mathrm{~h}$. The reaction mixture was diluted with $\mathrm{H}_{2} \mathrm{O}$ and extracted twice with ethyl acetate. The organic layers were combined, washed with brine, dried over $\mathrm{MgSO}_{4}$, filtered and concentrated to dryness. The residue was purified by flash chromatography (50\% ethyl acetate/ hexanes) to afford the title compound as a white solid (268 mg, 77\%, two steps). The ${ }^{1} \mathrm{H}$ and ${ }^{13} \mathrm{C}$ NMR spectra and $\alpha_{\mathrm{D}}((589 \mathrm{~nm}, 11.6$ $\left.\mathrm{mg} / \mathrm{mL} \mathrm{CHCl}_{3}\right)=-4$ ) were consistent with a literature report. ${ }^{19}$

(-)-Paroxetine (4).
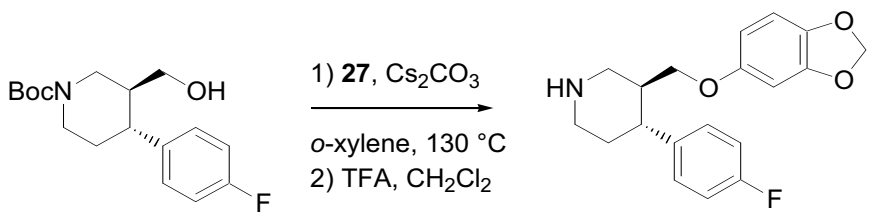

Primary alcohol 26 (195 mg, $0.629 \mathrm{mmol}), 27$ (239 mg, $0.818 \mathrm{mmol})$ and $\mathrm{Cs}_{2} \mathrm{CO}_{3}(308 \mathrm{mg}, 0.944 \mathrm{mmol})$ were mixed in $o$-xylene $(1 \mathrm{~mL})$ in a $15 \mathrm{~mL}$ Schlenk tube under $\mathrm{N}_{2}$. The tube was sealed with a Teflon screw cap and warmed to $130{ }^{\circ} \mathrm{C}$. After $20 \mathrm{~h}$, the mixture was cooled to ambient temperature, ethyl acetate was added and the mixture was filtered through a pad of celite. The filtrate was concentrated to dryness, dissolved in $\mathrm{CH}_{2} \mathrm{Cl}_{2}(1 \mathrm{~mL})$ and TFA (1 mL) was added. After 15 minutes, $\mathrm{NaOH}(1 \mathrm{~N})$ was added and the mixture was extracted four times with $\mathrm{CH}_{2} \mathrm{Cl}_{2}$. The organic layers were washed with brine, filtered through cotton, and concentrated to dryness. The residue was purified by flash chromatography ( $5 \%$ diethyl amine/ ethyl acetate) to afford the title compound as an oil (99 $\mathrm{mg}, 48 \%$ over two 
steps). ${ }^{1} \mathrm{H}$ NMR, ${ }^{13} \mathrm{C} \mathrm{NMR}$, IR and $\alpha_{\mathrm{D}}\left(\left(589 \mathrm{~nm}, 16.1 \mathrm{mg} / \mathrm{mL} \mathrm{CHCl}{ }_{3}\right)=-83\right)$ were found to be consistent with literature reports. ${ }^{19}$

${ }^{19}$ Amat, M.; Boch, J.; Hidalgo, J.; Canto, M.; Perez, M.; Llor, N.; Molins, E.; Miravitlles, C.; Orozco, M.; Luque, J. J.Org.Chem. 2000, 65, 3074. 